NBER WORKING PAPER SERIES

\title{
THE EFFECT OF SCHOOL CHOICE ON STUDENT OUTCOMES: EVIDENCE FROM RANDOMIZED LOTTERIES
}

\author{
Julie Berry Cullen \\ Brian A. Jacob \\ Steven Levitt
}

Working Paper 10113

http://www.nber.org/papers/w10113

\author{
NATIONAL BUREAU OF ECONOMIC RESEARCH \\ 1050 Massachusetts Avenue \\ Cambridge, MA 02138 \\ November 2003
}

\begin{abstract}
We would like to thank John Dinardo, Gary Solon, and numerous seminar participants for useful comments and suggestions. We are grateful to John Easton, Joseph Hahn, Dan Bugler, Jack Harnedy, Frank Spoto and John Quane for assistance in collecting the data, and to Patrick Walsh and Sara Lalumia for excellent research assistance. The National Science Foundation provided partial funding of this research. Portions of this paper were written while Levitt was a fellow at the Center for the Advanced Study of Behavioral Sciences in Stanford, CA. Addresses: Julie Cullen, Department of Economics, University of Michigan, Ann Arbor 48109-1220,jbcullen@umich.edu; Brian Jacob, Kennedy School of Government, Harvard University, 79 JFK Street, Cambridge, MA 02138, Brian_Jacob@harvard.edu; Steven Levitt, Department of Economics, University of Chicago, 1126 East 59 ${ }^{\text {th }}$ Street, Chicago, IL 60637, slevitt@midway.uchicago.edu. All remaining errors are our own. The views expressed herein are those of the authors and not necessarily those of the National Bureau of Economic Research.

(C2003 by Julie Berry Cullen, Brian A. Jacob, and Steven Levitt. All rights reserved. Short sections of text, not to exceed two paragraphs, may be quoted without explicit permission provided that full credit, including (C) notice, is given to the source.
\end{abstract}


The Effect of School Choice on Student Outcomes: Evidence from Randomized Lotteries Julie Berry Cullen, Brian A. Jacob, and Steven Levitt

NBER Working Paper No. 10113

November 2003

JEL No. I28, H72

\section{ABSTRACT}

School choice has become an increasingly prominent strategy for urban school districts seeking to enhance academic achievement. Evaluating the impact of such programs is complicated by the fact that a highly select sample of students takes advantage of these programs. To overcome this difficulty, we exploit randomized lotteries that determine high school admission in the Chicago Public Schools. Surprisingly, we find little evidence that attending sought after programs provides any benefit on a wide variety of traditional academic measures, including standardized test scores, attendance rates, course-taking, and credit accumulation. This is true despite the fact that those students who win the lotteries attend better high schools along a number of dimensions, including higher peer achievement levels, higher peer graduation rates, and lower levels of poverty. We do, however, uncover evidence that attendance at such schools may improve a subset of non-traditional outcome measures, such as self-reported disciplinary incidences and arrest rates.

Julie Berry Cullen

Department of Economics

University of Michigan

Ann Arbor, MI 48109-1220

and NBER

jbcullen@umich.edu

Brian A. Jacob

Kennedy School of Government

Harvard University

79 JFK Street

Cambridge, MA 02138

and NBER

brian_jacob@harvard.edu
Steven Levitt

Department of Economics

University of Chicago

1126 East $59^{\text {th }}$ Street

Chicago, IL 60637

and NBER

slevitt@midway.uchicago.edu 


\section{Introduction}

Although the current school choice debate centers on private school vouchers and charter schools, the most common form of choice available to students in urban areas is open enrollment (NCES 1996). Under open enrollment, public school students can apply to gain access to magnet public schools and programs outside of their neighborhood school. This form of choice is likely to become even more prevalent under the recent federal education legislation No Child Left Behind (NCLB). School districts that accept Title I funds must allow students at lagging schools to attend other schools in the district, giving preference to low achieving and low income students. A necessary condition for this form of choice to improve student achievement is that those students who gain access to desirable schools experience better academic outcomes than they otherwise would.

Much of the evidence on the link between access to school choice and student outcomes comes from contexts other than open enrollment, and estimating a causal relationship has proven difficult. Observational studies of private schools (Coleman et. al. 1982, Bryk et. al. 1993) and magnet schools (Blank 1983; Metz 1986; Gamoran 1996) find that students who attend these schools experience better educational outcomes, but these studies potentially suffer from important selection bias since the students who take advantage of school choice are unlikely to be representative of students more generally. Studies that use instrumental variables approaches to account for endogenous school choice find mixed effects, with some showing benefits of attending Catholic schools (Evans and Schwab 1995) and others showing little or no effect (Sanders 1996, Neal 1997). ${ }^{1}$ More recently, there have been a series of studies that exploit randomized voucher lotteries to estimate the effect of attending a private school. The Milwaukee voucher program, offering vouchers to a limited number of low-income students to attend one of 
three private nonsectarian schools in the district, is the most prominent of these. Analyses of this program obtain sharply conflicting estimates of the impact on achievement depending upon the assumptions made to deal with selective attrition of lottery losers from the sample (Witte, Sterr et al. 1995; Green, Peterson et al. 1997; Witte 1997; Rouse 1998). Although in theory randomization provides an ideal context for the evaluation of school choice, in the Milwaukee case less than half of the unsuccessful applicants returned to the public schools and those who did return were from less educated, lower income families (Witte 1997). ${ }^{2}$

In this paper, we are able to overcome many of the empirical difficulties confronting earlier studies by using detailed administrative data from the Chicago Public Schools (CPS). Like the Milwaukee voucher experiment, we avoid the issue of non-random selection into school choice by using lottery data. Many CPS schools use lotteries to allocate spots when oversubscribed. In this paper, we use lottery data from 194 separate lotteries at 19 high schools. The CPS data we use offer a number of important advantages over the Milwaukee experiment. First, selective attrition is less of a concern in our sample since more than 90 percent of lottery participants remain in CPS, and losing a lottery has only a minor impact on a student's propensity to stay. Moreover, there is little evidence that those who remain in the sample differ on observable dimensions from those who leave. Second, we have access to a far broader range of student outcomes than is typically available. In addition to standard achievement and attainment measures, we also have student survey responses covering their degree of satisfaction

\footnotetext{
${ }^{1}$ Altonji et al. (2002) suggests that the IV strategies used in prior studies may not be valid.

${ }^{2}$ An additional limitation to studies of the Milwaukee program is that direct information on the schools that students applied to is not available, forcing researchers to impute likely application schools (see Rouse 1998 for details).

Evidence from other voucher experiments is similarly mixed. Peterson et al. (1998) and Howell and Peterson (2002)

find that the opportunity to attend a private school modestly increases student achievement for low-achieving African-American students in New York City, Dayton, OH and Washington, DC. A reanalysis of the New York City experiment by Krueger and Zhu (2003), however, suggests that even claims of modest benefits may be overstated. Studies of private school choice in other countries find improved educational and social outcomes (Angrist et. al. 2002). Prior studies that exploit lotteries to examine the benefit of attending magnet schools with a
} 
with the school attended, how they are treated by teachers and peers, expectations about college attendance, and self-reported arrest data. ${ }^{3}$ Understanding how reforms affect these nontraditional measures of student outcomes is an area about which little is known and of great importance, particularly in light of the frequent inability of school-based interventions to induce large changes in standard educational measures like test scores (Hanushek 1997). Third, CPS has been one of the most aggressive school districts in the country in implementing intra-district school choice. Over half of high school students in CPS take advantage of the program by attending a school other than the one they are assigned, allowing us to examine the benefits of a systemic program rather than one where a small percentage of children participate. Finally, the type of school choice we analyze in this paper is particularly relevant to the current federal accountability mandate insofar as our analysis focuses on public schools in a large, disadvantaged urban district.

Our use of lotteries as the source of identifying variation permits straightforward analysis based on comparisons of means. In principle and in practice, controlling for other characteristics will have little impact on any conclusions drawn, although we do so to increase the precision of our estimates. Sample selection in terms of which students choose to apply to a particular school will not bias our estimates, since among the applicants to a given school, those who win or lose the lottery will on average have the same characteristics. ${ }^{4}$

Comparing lottery winners and losers, we find little evidence that attending sought after

\footnotetext{
vocational focus find mixed evidence of any long-term benefit (Crain et. al. 1992, 1999; Kemple and Snipes 2000).

${ }^{3}$ Few studies have examined the effects of specialized schools on non-traditional outcome measures for students. Two recent studies examine the impact of Catholic schools on non-market behaviors such as drug use, sexual behavior and criminal activity, finding opposite results (Figlio and Ludwig 2000, Mocan et. al. 2002). Randomized housing mobility experiments show that households offered vouchers to low-poverty neighborhoods experience increased safety, fewer behavior problems, and improved health outcomes (Katz et. al. 2001).

${ }^{4}$ Although one does still need to use care in properly interpreting the resulting parameter, which is an unbiased estimate of the impact of winning a lottery for the students applying to the lottery, but may not generalize to other students in the system.
} 
programs provides any benefit on a wide variety of traditional achievement measures, including standardized test scores, attendance rates, course-taking patterns, and credit accumulation. These results are robust to a variety of sensitivity analyses, and do not vary substantively across student subgroups. This finding is surprising since students who win contested lotteries would be expected to fare better academically for a number of reasons. They might gain access to better resources, better peers, or be able to attend a program that better suits their learning needs for idiosyncratic reasons.

We explore a variety of possible explanations for the lack of academic benefits that would still be consistent with schooling choices being driven by the anticipation of such benefits. These include: students winning lotteries end up attending similar schools to those who lose (i.e., the "treatment" is limited); students who are selected have to travel much greater distances to school; attendance at a choice school is a substitute for parental involvement. None of these hypotheses has much explanatory power. Those students who win lotteries to the most select programs do end up attending what appear to be substantially better high schools - e.g., schools with higher achievement levels and graduation rates and lower levels of poverty. And, we find little evidence that excess travel or parental compensation mitigate potential achievement gains.

The coexistence of intense competition for entry and little academic benefit to students attending lottery schools could indicate that parents are not well-informed about the education production function, and mistake higher outputs for higher value added. Alternatively, parents and children might apply to magnet schools for predominantly non-academic reasons, in which case systematic academic gains would not be expected. Using a unique set of survey data on student attitudes and behaviors, we examine the impact of winning a lottery on measures such as enjoyment of school, behavior of peers, student-teacher trust, expectations for the future, and 
self-reported disciplinary incidents. If parents and children choose schools for non-academic reasons, one would expect positive effects on these non-traditional outcomes. We find some, though limited, support for this hypothesis: winners report lower incidences of disciplinary action and fewer arrests, but are no more likely to report positive outcomes on other measures such as liking school, trusting their teachers, and having high expectations for the future.

Overall, our findings suggest that parents and children are not choosing schools that provide significant academic benefit to them, and may be choosing schools for other reasons. More importantly, this analysis suggests that open enrollment is unlikely to be an effective mechanism to improve academic achievement in urban school districts (as envisioned by NCLB). However, it may confer other benefits not captured by test scores or traditional outcome measures, such as matching idiosyncratic tastes of parents and students and improving social circumstances.

An important caveat to interpreting our results is that we are only able to evaluate the partial equilibrium effects of school choice. In other words, the lotteries allow us to estimate how winning access to a particular school affects educational outcomes for a student, holding constant the existence of a school choice program. We are unable to determine how the introduction of a school choice system affects outcomes, since the introduction may have altered the composition of students in the public sector, the overall level of public school quality (e.g., Hoxby 2000), and residential location patterns.

The remainder of the paper is structured as follows. Section II provides background on magnet schools in CPS, the lotteries, and the administrative data. Section III describes our estimation strategy, focusing on how we utilize the lottery randomizations. Section IV analyzes 
the impact of lottery outcomes on a variety of traditional and non-traditional outcome measures. Section V concludes.

\section{Institutional detail and data description}

The Chicago Public Schools have one of the most extensive school choice programs available. $^{5}$ Each student is guaranteed admission to an assigned neighborhood school, but can also apply to any other CPS school. Indeed, more than half of all high-school students in CPS in 2000 and 2001 exercised their choice and elected not to attend their assigned school.

In order to attend a school other than the assigned school, a student must submit an application in the spring of the preceding year. A student must reside within the school district, but does not need to be currently enrolled in CPS in order to submit an application, and there is no restriction placed on the number of applications an individual student can submit. In most cases, if the number of applicants exceeds the number of available positions, randomized lotteries are used to determine the allocation of spots. For a limited number of programs, typically the most selective, admission is based on criteria such as test scores, and lotteries are not used.

For programs using lotteries, there are explicit rules governing the way in which the lotteries are conducted. Because of desegregation goals and variation in the number of available slots at different grade levels, separate lotteries are conducted for each gender-race-grade combination. A particular school may also house multiple separate magnet programs, each of

\footnotetext{
${ }^{5}$ School choice was first instituted in Chicago in response to a 1980 desegregation consent decree with the federal government. The goal of the consent decree was to create schools whose racial composition roughly matched the racial composition of the school system. Since that time, the size and scope of school choice has expanded dramatically.
} 
which would conduct separate lotteries. As a consequence, one school can potentially have a large number of lotteries each year. ${ }^{6}$

Working with the CPS, we have obtained detailed administrative data on applications submitted in spring 2000 and spring 2001. The application data include the name, race, gender, date of birth, home address, current school, and grade of each applicant, as well as the program a student is applying to, whether that application was part of a lottery, and if so, the lottery outcome. We focus on eighth grade students applying for ninth grade admission. This is the transition period from grade school to high school in CPS and thus is the juncture at which school choice is most frequently exercised. ${ }^{7}$

We exclude the small fraction (7 percent) of eighth grade students applying from outside CPS. Note that excluding these students does not affect the validity of the randomization since enrollment status at the time of application is a predetermined variable. These students are no more or less likely to be represented among winners than among losers of any given lottery. However, excluding these students greatly reduces problems of selective attrition. They are much less likely to enroll in CPS the following year, particularly when losing the lottery. ${ }^{8}$

For our sample of eighth-grade applicants attending public schools in the district, the application data also provide their CPS identification number. Using this number, we link each application to a student's school records. This provides us with not only information on demographics and prior school performance of the student, but also information on whether the

\footnotetext{
${ }^{6}$ There is a further layer of complexity with regard to lotteries, namely that schools also reserve a share of available seats and conduct special lotteries for siblings of current students ("sibling lotteries") and for students who live nearby ("proximity lotteries"). Because such lotteries are rarely oversubscribed, they do not provide useful variation for our empirical work.

${ }^{7}$ The only other grade within CPS for which there is substantial numbers of school assignments allocated by lottery is kindergarten. The 2000 and 2001 cohort of kindergarten applicants will complete third grade in 2004 and 2005 respectively, at which point test score data will become available.

${ }^{8}$ Applicants for $9^{\text {th }}$ grade slots from eighth-graders not enrolled in CPS during $8^{\text {th }}$ grade are $35 \%$ more likely to enroll in the CPS if they win a contested high school lottery than if they lose. This provides evidence that the
} 
student enrolled in the CPS the following year and, if so, all of the student's outcomes (See Appendix A for a detailed description of the variables and data sources used in this study). Our data has the shortcoming that we do not observe outcomes for students who do not attend CPS in subsequent years.

After eliminating applications to schools that do not use lotteries to assign slots (a handful of very selective test-based schools), special education schools, and schools with incomplete lottery outcome data, we are left with a baseline sample of 19 schools and 194 lotteries. ${ }^{9}$ Our baseline sample contains 19,520 applications submitted by 14,438 students. The students in our sample represent approximately one-fourth of all eighth graders in CPS during this two-year period.

Table 1 presents information about the 19 schools represented in the data set. Schools are listed according to the eighth grade test score performance of students enrolling in ninth grade, with the highest achieving schools listed first. These schools range from the top ten percent among the 70 regular high schools in CPS along the test score dimension (Chicago Agricultural) all the way down to the very bottom (Orr is the second lowest scoring high school in CPS). For purposes of analysis, we divide these schools into two groups: "high achieving" and "other." Somewhat arbitrarily, we assign the first five schools to the high achieving category and the remaining schools to the other category. Later in the paper, we explore the sensitivity of our results to alternative classifications of schools. The schools in our sample exhibit substantial racial heterogeneity (ranging from more than half White to all minority), differences in selectivity of the lotteries (only 2.9 percent of lottery applicants are admitted in Von Steuben compared to 53 percent at George Washington), and widely varying take-up rates

availability of school choice serves to attract students to the public sector.

${ }^{9}$ Appendix A describes the construction of our sample in greater detail. 
among lottery winners (as high as 64.7 percent at Curie and as low as 6 percent at Lake View).

Overall, these lotteries are quite competitive. On average, only 15 percent of applicants actually win in a particular lottery. Because a student can apply to multiple lotteries, roughly 20 percent of the students in the sample win at least one lottery.

Analysis of the raw data at the student level in Table 2 clearly demonstrates the important differences between the pool of applicants entering our lotteries (column 1) and other eighth grade students in CPS (column 2) along a variety of dimensions. Students entering lotteries are less likely to be Black or male, have substantially lower test scores, and are less likely to be poor (as proxied by free lunch eligibility and census tract poverty rates). Given the substantial differences in observable characteristics, one might also be concerned that lottery applicants may also be systematically different on unobservable dimensions (for example, motivation level, parental involvement, etc.). It is precisely for this reason that lottery-induced randomization is likely to be important for drawing conclusions about the causal impact of school choice on student outcomes.

\section{Empirical strategy}

In theory, lottery-induced randomization provides a simple solution to the problem of endogenous sorting of students. Because lottery outcomes are randomly assigned, winners and losers of a particular lottery have the same set of background characteristics on average, both for observables and unobservables. Consequently, a simple difference of observed student outcomes between students who win and lose the lottery provides a consistent estimate of the impact of winning the lottery. ${ }^{10}$

\footnotetext{
${ }^{10}$ One can also condition on observable student characteristics in constructing the estimate. In large samples, the estimates will be the same with and without conditioning on observables, as long as there is no selective attrition
} 
In the presence of $J$ independently conducted lotteries, we could in principle generate $J$ different estimates $\delta_{j}$ that capture the marginal impact of being admitted to the school represented by lottery $j$ :

$$
\delta_{j}=E\left[Y_{i} \mid \operatorname{Win}_{i j}=1\right]-E\left[Y_{i} \mid \operatorname{Win}_{i j}=0\right]
$$

where $Y$ is some outcome measure for student $i$ and $\operatorname{Win}_{i j}$ is a binary variable indicating whether the student won lottery $j$. Then, $\delta_{j}$ indicates whether winners are systematically higher or lower on the characteristic $Y$ than losers in the same lottery.

While $\delta_{j}$ is clearly an unbiased estimate of the impact of winning this lottery, it is important to consider its interpretation. The parameter measures the impact of winning conditional on the characteristics of the applicants. Particularly relevant is the case where applicants apply to more than one lottery. Because students may win other lotteries (10 percent of losers in our sample win another lottery) and not all winners choose to attend the lottery school, $\delta_{j}$ measures the impact of having the option to attend the lottery school. Importantly, as long as the lottery is truly randomized and there is no selective attrition, the parameter estimate is an unbiased estimate of this intention-to-treat (ITT) effect even if we are missing background information about other schools to which a student may have applied or been accepted.

It is also legitimate to estimate separate treatment effects for subgroups of students, as long as the sample is split according to characteristics that are predetermined at the time of application. For example, the impact of winning for students in lottery $j$ with a specific value for a characteristic $z$ would be:

from the original sample. In small samples such as ours, controlling for observable characteristics will correct for any imbalances that arise on these dimensions in a particular draw. The addition of covariates will also improve the precision of the estimates. 


$$
\delta_{j k}=E\left[Y_{i} \mid \operatorname{Win}_{i j}=1 ; z_{i}=k\right]-E\left[Y_{i} \mid \operatorname{Win}_{i j}=0 ; z_{i}=k\right]
$$

That is why excluding students who are not enrolled at the time of application does not introduce any bias, but rather, merely alters the interpretation of the estimates.

In practice, the standard errors for particular lotteries and subgroups within lotteries are too large to make such estimates informative. Therefore, we instead report results from ordinary least-squares regressions of the form:

$$
Y_{i}=\delta_{1}\left(\text { Win_High }_{i a}\right)+\delta_{2}\left(\text { Win_other }_{i a}\right)+\Gamma\left(\text { Lottery }_{a}\right)+e_{i a},
$$

where the subscripts $i$ and $a$ index students and applications, respectively. Win_High ia a binary variable that indicates whether application $a$ for student $i$ was a winner at a lottery to a high-achieving school (92 of our lotteries). Win_Other ${ }_{i a}$ reflects whether this application won a lottery to a non-high-achieving school (102 of our lotteries). Lottery ${ }_{a}$ is a vector of fixed effects indicating the lottery to which the observation refers, and $e$ is a stochastic error term. In this specification, the $\delta$ coefficients are simply applications-weighted averages of the $\delta_{j}$ 's for the lotteries belonging to each of the two school categories. In some specifications, we include covariates such as student demographics, prior achievement and neighborhood characteristics. ${ }^{11}$ Since the same student is included in the regression more than once if he or she submits multiple applications (we have roughly 1.3 applications per student), we report robust standard errors that account for clustering at the student level. When we examine high school outcomes, we report robust standard errors that account for clustering at the school level. ${ }^{12}$

\footnotetext{
${ }^{11}$ Note that this specification restricts the coefficients of other covariates to be the same for applications to highachieving and other schools. Relaxing this assumption does not change any of our estimates.

${ }^{12}$ Technically, the standard errors should reflect the correlation structure at the student as well as the school level. The precision of the estimates from the equation that treats the student rather than the application as the unit of observation (presented as a sensitivity test) suggests that standard errors adjusted for clustering at both levels would be quite similar to the ones we report.
} 
We prefer the above specification that treats the application as the unit of analysis since this is the point at which randomization occurs. However, it is also possible to specify alternative models with the student as the unit of observation. Consider the following equation:

$$
Y_{i}=\delta_{1}^{\prime}\left(\text { WinOne_High }_{i}\right)+\delta_{2}^{\prime}\left(\text { WinOne_Other }_{i}\right)+\Pi\left(\text { Apps }_{i}\right)+u_{i},
$$

where $\mathrm{WinOne}_{-} \mathrm{High}_{i}$ is a binary indicator of winning at least one lottery to a high-achieving school, WinOne_Other $r_{i}$ is a binary indicator of winning at least one lottery to a non-highachieving school, and Apps $_{i}$ is a vector of indicators capturing the set of lotteries to which the student applied. ${ }^{13}$ In the case where all students only apply to only one lottery, this equation is identical to equation (3). While this strategy may be somewhat easier to interpret than the previous specification, one shortcoming of this strategy is that it uses less information. For example, if only one student applied to a particular combination of schools, the observation for this student would not be used in estimating the impact of winning a lottery. As a sensitivity check, we re-estimate our main results using this specification and find very similar results. Note, however, that the treatment effects in (3) and (4) measure different things and are not directly comparable. The strategies will produce somewhat different results if many students apply to and win lotteries at multiple schools, and the impact of winning more than one lottery strongly affects the likelihood of attending that type of school.

\section{Establishing the validity of the randomization}

If the lotteries were conducted properly, then one would predict that the winners and losers of a given lottery will be, on average, perfectly balanced on all predetermined

\footnotetext{
${ }^{13}$ This is analogous to the specification used by Dale and Krueger (2002) in estimating the payoff to attending a more selective college and by Rouse (1998) in examining the Milwaukee choice program. Note that it is not sufficient to include a single dummy for each lottery. Instead, one must include a separate fixed effect for every
} 
characteristics. We test this proposition by estimating equation (3) for a series of demographic and prior achievement variables. The results are compiled in Table 3. Columns 1 and 2 present coefficient estimates on $\mathrm{Win}_{-} \mathrm{High}_{i a}$ and $\mathrm{Win}_{-} \mathrm{Other}_{i a}$, respectively, along with robust standard errors that account for correlation across applications by the same student in parentheses. We show the control group means (i.e., values for those who lost the lottery) in brackets. Each row represents a separate regression corresponding to a different dependent variable. Studentspecific characteristics are shown in the top panel; school and neighborhood characteristics are shown in the bottom panel. The results of Table 3 confirm that lottery winners and losers appear similar on a wide range of observable characteristics at the time when the lottery applications are submitted. There are actually fewer significant differences between lottery winners and losers across the twenty characteristics considered than might be expected by chance. ${ }^{14}$

\section{Selective attrition}

Even if the lotteries were properly carried out, selective attrition may bias our findings since we only observe subsequent student outcomes if the student enrolls in CPS. Table 4

possible combination of lotteries to which students can apply.

${ }^{14}$ This test indicates whether winners are systematically better or worse than losers across the lotteries. Even if there are no differences on average, however, it is theoretically possible for winners to be better in some lotteries and worse in other lotteries, calling into question the validity of the randomization. One approach to testing this hypothesis is to estimate a model similar to equation (3) that includes separate indicators for winning each particular lottery and then conduct an F-test on the joint significance of the set of variables that indicate winning a lottery. The problem with that strategy is that because we have many very small lotteries we must rely on the assumption that the dependent variables are distributed normally in the population, which is clearly not true for the binary outcomes.

For this reason, we take a different approach. For our binary background characteristics, we calculate Fisher's exact p-value for the difference in proportions across winners and losers for each lottery. For the continuous background characteristics, we calculate the p-value from unpaired t-tests for the difference in means across winners and losers (which in small samples requires the maintained assumption of normality of the underlying distribution in the population). Because the Fisher exact p-values are not continuous, these statistics may not be less than 0.05 in fivepercent of the cases. Hence, we use a permutation test (whereby participants in a given lottery are repeatedly randomly assigned to winning or losing at the same rates as in the actual lottery) to determine the expected distribution of p-values across the background characteristics and lotteries. Comparing expected and actual distributions of p-values using chi-squared tests, we cannot reject random assignment. This is not surprising given that the lottery outcomes were computer-generated and the output was write-protected to prevent tampering. 
demonstrates that the issue of selective attrition in the Chicago data is much less severe than in previous studies, both in terms of overall attrition rates and whether attrition is correlated with characteristics that may influence subsequent achievement. The first column of the table reports ninth grade enrollment rates for lottery losers in square brackets, along with the regression estimates of the impact that winning a lottery has on enrollment. The regression estimates are based on equation (3), using an indicator variable for whether the student enrolls in CPS in ninth grade as the dependent variable.

Winning a lottery to a high-achieving school increases the probability of enrollment by four percentage points ( 4.6 percent) and winning other lotteries raises enrollment rates by one percentage point, although the latter estimate is not statistically different from zero. While these results demonstrate that there is some differential attrition between winners and losers of lotteries to high-achieving schools, the remaining columns suggest that the differential attrition is not selective - that is, the attrition does not appear to be correlated with observable characteristics that may influence subsequent outcomes. Columns 2-5 show the effects of winning a lottery on prior student achievement and demographics among the sample of students who enrolled in the CPS in $9^{\text {th }}$ grade. If the losers who left the CPS were systematically different than the winners who left, then we would expect the coefficients on winning a lottery to be different than zero. However, the estimates shown in columns 2-5 are statistically insignificant and very small in magnitude. ${ }^{15}$ Given the low levels of attrition, it is not particularly surprising that the randomization continues to perform well on the subset of students who enter ninth grade.

\footnotetext{
${ }^{15}$ Because of space constraints, we present results for a representative subset of the characteristics included in Table 3. For two of the 20 dependent variables (mean achievement in the $8^{\text {th }}$ grade school and fraction homeowners in $8^{\text {th }}$ grade census tract), the coefficient on the indicator for winning a lottery to a high-achieving school are significant at the five percent level; none of the 20 coefficients on winning a lottery to other schools are significant at either the five or ten percent levels.
} 
Even if the differential enrollment attrition is minor and not correlated with any observable student characteristics, it is still possible that, conditional on enrollment, winners and losers may have different propensities to have valid outcome data. This might be the case if, for example, lottery losers become discouraged and while still attending school, do not show up to take the standardized achievement exams at a greater rate than lottery winners. To examine this issue of outcome attrition, we estimated models similar to those shown in Table 4 and find no

evidence of systematic selection in the presence of missing data. As a final check, we conduct a series of sensitivity analyses and selection corrections, which further confirm that our results are unlikely to be heavily influenced by attrition (see Appendix B for more detail and the relevant regression results).

\section{Section IV: The impact of winning a lottery on student outcomes}

To estimate the effect of winning a lottery on student outcomes, we estimate equation (3) using outcome variables on the left-hand-side of the regression. Because the unit of analysis is an application, the coefficient reflects the impact of winning a particular lottery. It is likely that there is substantial heterogeneity in the impact that winning a lottery will have on student outcomes, depending for instance on the student's next best schooling option. We begin by focusing on the average impact of winning across all participants in the lotteries at the two types of schools, and then attempt to identify heterogeneous treatment effects as a function of a variety of observable student characteristics

Table 5 presents results where the outcome measures are characteristics of the high school the student attends. Knowing how the schooling environment differs between winners and losers helps to establish how the intention-to-treat translates into an average treatment for 
winners. Each row of the table presents a separate regression corresponding to the dependent variable named in the first column. The values reported in the second and third columns are the $\delta$ coefficients, the standard errors, and the control group means. Note that the specifications reported here include a series of student demographic and prior achievement variables (detailed in the notes) as covariates.

The results demonstrate that lottery outcomes have a substantial impact on the high schools students attend within CPS. In the top panel of Table 5, the dependent variables are a series of indicator variables for the type of school attended. The top row, for instance, shows that winning a lottery to a high-achieving school increases the probability a student attends the school for which the lottery is held by 36.3 percentage points. For lotteries to other schools, winning the lottery increases the likelihood that the student enrolls at that school by 23.5 percent. Note that some students who lose the lottery nonetheless are sometimes able to enroll in the school, although the rates are low (8.2 percent for high-achieving schools, 5.5 percent for other schools). That is because there are sometimes multiple programs offered within a given school, some of which may not be oversubscribed. ${ }^{16}$

Winning a lottery has a smaller effect on whether a student attends any lottery school or any school other than the assigned school. Some of the students who win this particular lottery will also win other lotteries or will apply to schools that do not use lotteries. Winning a lottery to a high-achieving school is positively related to attending high-achieving schools. Winning other lotteries is weakly negatively related to attending high-achieving schools, presumably because the student sometimes accepts the lottery-generated spot at the low-achieving school even though there was the option of attending a different, high-achieving school. Winning either type of

\footnotetext{
${ }^{16}$ Unfortunately, we only know the school in which a student is enrolled, and not the particular program within the school. Another channel through which lottery losers could gain access to the school is through the discretion that
} 
lottery reduces the likelihood a student will attend either of the sought after types of schools that do not use lotteries: selective admissions schools and career academies.

The bottom panel of Table 5 explores the impact that winning a lottery has on the characteristics of the school that a student attends (regardless of whether the student actually chooses to go to the school at which he or she wins the lottery). On average, students winning lotteries to high-achieving schools attend schools with peers who test substantially higher on standardized tests, have lower rates of poverty as measured by free lunch eligibility, and have higher graduation rates. ${ }^{17}$ The schools attended are in higher income and lower crime neighborhoods. Thus, on a wide range of dimensions that might be expected to reflect school quality, lottery winners go to better schools than students entering but losing the same lottery to high-achieving schools. Winning a lottery to other schools also increases the average characteristic of the school attended, but generally by a much smaller margin.

One would expect that lottery winners would experience improved academic outcomes, both because they are attending higher quality schools on average and because their choice set is increased. To the extent that there are idiosyncratic features of a student-school match that the student observes, but we do not, winning a lottery may improve student outcomes even without a change in our proxies for school quality.

Table 6 presents surprising results to the contrary. Each row of Table 6 corresponds to a different regression with a traditional measure of school performance on the left-hand side and standard errors clustered to account for the correlation among students within the same $9^{\text {th }}$ or $10^{\text {th }}$ grade high school. The specifications estimated are otherwise identical to those in Table 5.

Overall, we find no evidence that students winning lotteries to select schools perform better on

principals have to admit a small number of students outside of the lottery process.

${ }^{17}$ Table 7 also reveals that winners in high-achieving school lotteries are much more likely to have ready access to 
any of several academic achievement measures. Indeed, students winning lotteries to highachieving schools perform slightly worse on four of the six standardized tests administered in ninth and tenth grade, although the difference is only statistically significant for $10^{\text {th }}$ grade reading scores. ${ }^{18}$ There are also no significant differences between lottery winners and losers at high-achieving schools on dropout rates through tenth grade, absences, or course credits.

Students winning lotteries to other schools also appear to perform no differently than lottery losers, with only one statistically significant exception $\left(9^{\text {th }}\right.$ grade reading $)$ in which the lottery winners perform worse.

Despite the limited size of many of the lotteries, the estimates are reasonably precise. The test of $9^{\text {th }}$ grade reading scores, for example, is able to detect effects of 1.4 percentage points in comparison with a control group mean of 46.8 . Given that the point estimates for many of the test score outcomes are negative, the $95 \%$ confidence intervals around the estimate suggest it is highly unlikely that winning a lottery to a magnet school has a positive effect of any substantive magnitude. The minimum detectable effects for $9^{\text {th }}$ grade absences and credits are 0.82 and 0.32 respectively. Given the standard deviation of these outcomes among the control group is 11.5 and 2.5 respectively, the power of the estimates for the transcript outcomes is also high.

Table 7 analyzes the sensitivity of our findings to alternative specifications, choices of sample, and school classifications. Our baseline results are reprinted in the first column. The second column re-estimates the results using a student as the unit of observation instead of an application. In this column, instead of including lottery fixed-effects as controls, we include

computers. This suggests that winners are exposed to higher levels of school resources.

${ }^{18}$ We have also explored possible non-linearities in the impact of winning a lottery by looking at whether winning a lottery affects the likelihood that a student will perform in the top or bottom quartile of the standardized test distribution. We find no systematic impact of winning a lottery on whether a student tests in the bottom quartile. We do, however, find that high-achieving school lottery winners are systematically less likely to test in the top quartile on standardized tests, with the results statistically significant at the .05 level on two tests and at the .10 level on a third test. 
dummies for each possible combination of lotteries to which a student could apply. None of the results are materially affected, which is not surprising given that the modal student in our data applies to only one lottery in our sample. Excluding small lotteries has no impact on the estimates. When we make our definition of high achieving schools stricter, the impact on a student's peers is greater, and reductions in arrest rates are particularly large, but other outcomes measures are unaffected. Correspondingly, when we relax the requirements for being classified as high achieving, the opposite pattern emerges.

The final three columns are particularly noteworthy. Given that students may be applying to specific magnet programs within high schools, it is possible that students are selecting programs that match their academic goals in ways that would not be expected to show up in higher academic achievement. To test this hypothesis, we divide the lottery high schools according to the types of programs that are offered. Consistent with our earlier findings, students winning lotteries at schools with a math focus do not obtain higher math scores (and obtain lower reading scores). And, those winning lotteries at schools with a reading focus actually score lower than losers on reading exams, while performing no worse on math exams.

Even if the aggregate effects are zero, it is possible that winning a lottery has a positive effect for some students. For example, in a series of voucher experiments, Peterson et. al. (1998) find that the opportunity to attend a private school increases student achievement for lowachieving African-American students, but not others (see also Howell and Peterson 2002). To explore this possibility here, Table 8 examines how the reduced-form results differ across subgroups, with each column representing a different subset of the student population. ${ }^{19}$ The first column presents results for the full sample as a baseline. The other columns show results for Blacks, Hispanics, Males, those with below average eighth grade test scores, relatively long trips 
to school, and students with low quality schools as their next best academic option within CPS. Not surprisingly, those students with low eighth grade test scores and bad outside options show the greatest responsiveness in terms of attendance decisions to winning a lottery and also experience the greatest increases in average peer test scores. Yet, there is no systematic pattern of positive achievement effects for any of the groups. None of the subsets exhibit any test score benefits in $9^{\text {th }}$ grade. Hispanic lottery winners have fewer absences than their peers in $9^{\text {th }}$ grade, but actually score lower on the reading exam. ${ }^{20}$ Hispanics and males do score significantly higher than other students on geometry in $10^{\text {th }}$ grade, but show no difference on the reading and English exams.

Given the absence of systematic academic benefits to students attending lottery schools, why is it that competition for entry is so intense? One simple explanation is that, absent good information about the education production function, families base their enrollment choices on school outputs. The most sought after schools in our sample do have higher outputs, but apparently due to better inputs, rather than extra value added. School quality is likely to be more of a blunt instrument for improving a given student's outcome than parents perceive. For example, if we assume that the benefits of winning a lottery operate entirely through increasing the quality of one's peers, and assume a peer effect of $0.1-0.2$, this suggests that that the 4.2 percentage point increase in peer $8^{\text {th }}$ grade test scores associated with winning a lottery to a highachieving school would translate into a roughly $0.4-0.8$ percentage point effect on a $9^{\text {th }}$ grade achievement score. $^{21}$ This is a small effect that we might not be able to detect. Note, however,

\footnotetext{
${ }^{19}$ Full results for all outcome measures in all sub-groups are available on request from the authors.

${ }^{20}$ None of the results presented in Table 8 are the result of selective attrition of lottery losers for a particular subgroup. Attrition estimates by subgroup are available from the authors upon request.

${ }^{21}$ The range of peer effects reported in prior research, even among the set of reasonably well-constructed studies, is quite large (Lefgren 2002). A broad reading of the literature suggests that 0.1-0.2 is a mid-range estimate. A recent study by Hanushek, Kain, Markman and Rivikin (2001) that examines public school students in Texas that utilizes student fixed effects and detailed administrative data finds estimates on the order of 0.1 .
} 
that for some subgroups (i.e. those with poor schooling alternatives) the change is much larger and that, for all students, lottery success changes a variety of dimensions of the student's high school experience at the same time, not just peer quality.

Even if the lottery winners are, on average, attending higher quality schools, other factors may mitigate any achievement benefits they receive. One possibility is that winners might have to travel greater distance to attend school than losers, and this reduces the time they can spend studying. ${ }^{22}$ Using the student home addresses provided in school records, we can measure the distance each student travels to school. The estimates on the bottom row of Table 5 indicate that students winning lotteries only travel an extra half-mile school on average compared with their peers who lose the lotteries. Given the number of choice options throughout the district, this is not necessarily surprising, but does suggest that extra travel time cannot explain the lack of apparent achievement effects.

Another possibility is that school quality and parental involvement are substitutes in the education production function. For example, parents whose children win lotteries to select magnet schools may feel less need to carefully monitor their children's academic progress or assist their children with their schoolwork. While such behaviors are generally difficult to measure, a survey administered to one cohort in our sample when these students were in the $9^{\text {th }}$ grade affords some insight. Students were asked a series of questions that capture both parental support of student learning and the level of parental supervision of their school and non-school activities.

The top panel of Table 9 provides evidence that some parental behaviors are indeed substitutes for school quality. The structure of the table is identical to the preceding tables,

\footnotetext{
${ }^{22}$ Of course, parents and students should factor this additional time cost into their decision to apply for and attend a choice school. It is possible, however, that ex-ante, parents and children underestimate the extent of this cost.
} 
except that the dependent variables are taken from student survey responses to a wide range of questions. The sample is restricted to students in our 2000 cohort that applied to schools that administered the survey. ${ }^{23}$ The top rows in the table reveal that parents of lottery winners to high-achieving schools are less likely to help with homework or check whether the student has completed homework. However, these same parents are actually more likely to discuss schoolrelated activities with the student, including homework. Finally, the parents of lottery winners do not appear to exert a greater or lesser degree of supervision over their children. While a benefit of school choice may be that parents of lottery winners trade less enjoyable for more enjoyable interactions with their children, it is not clear that home inputs are lowered in an absolute sense, so that it is unlikely home efforts are completely undoing school efforts.

Policymakers generally view open enrollment or other forms of school choice as a lever to raise academic performance. However, it is possible that parents and children seek alternative schooling environments for other reasons. Parents might be interested in ensuring a safer or more nurturing environment for their children; students may be interested in attending particular schools for extracurricular activities or for a different peer group. While many of these reasons may lead to improved life outcomes in the long-run, they are less likely to influence traditional academic achievement measures in the short-run. In this case, however, we would expect school choice to affect measures of school satisfaction, safety or expectations for the future.

The remaining rows of Table 9 examine the effect of winning a lottery on a variety of non-traditional student outcome measures. The results present a somewhat more optimistic picture for open enrollment. ${ }^{24}$ Students winning lotteries to high-achieving schools are

\footnotetext{
${ }^{23}$ Three schools (Von Steuben, Lake View, and Roosevelt) did not administer the survey.

${ }^{24}$ As a sensitivity test, we re-estimated the results shown in Tables 5 and 6 for this restricted "survey sample" and obtained comparable results (which are available from authors upon request), indicating that the more positive estimates for non-traditional outcomes are not simply a function of the different sample used in these estimations.
} 
significantly less likely to report that they were subject to disciplinary action at school, and much less likely to say they have been arrested. Self-reported arrest rates for students winning lotteries to high-achieving schools are less than half as high (3.9 percent) as for students losing such lotteries ( 8.9 percent). However, these students are not significantly more likely to expect to graduate college, enjoy school, have positive interactions with peers or teachers, or feel safe at school. And, winning a lottery to a non-high achieving school does not appear to provide any measurable benefits, even on these non-traditional outcome measures. Overall, these data present only a limited case for public school choice conferring non-academic benefits to the typical participant. ${ }^{25}$

\section{Conclusions}

This paper uses lottery outcomes to estimate the causal impact on student outcomes of access to public school magnet schools and programs. Although students often take advantage of winning a lottery by attending that school, and on average the schools lottery winners attend are better on observable dimensions than the schools attended by lottery losers, we observe no difference between winners and losers on traditional outcome measures such as test scores or school attendance. This is true for a variety of subgroups of students and does not depend on the program offered in the school. This does not appear to be due to winners traveling greater distances to school or because of compensating behavior on the part of parents. We do, however, find some evidence that winning a lottery is associated with positive outcomes on certain non-academic measures, namely self-reported disciplinary problems and arrests.

\footnotetext{
${ }^{25}$ Appendix C presents estimates of several representative non-traditional outcome measures separately by student sub-group. These outcomes follow a pattern similar to those of the traditional achievement outcomes shown in Table 8. Estimates for all of the non-traditional outcomes separately by sub-group are available from the authors upon request.
} 
Our finding concerning the absence of a positive impact of school choice and highquality peers on traditional student outcomes stands in contrast with most, but not all, studies on the topic. In particular, two previous studies using CPS data obtain similar results. Cullen, Jacob, and Levitt (forthcoming), using distance from a student's residence to schools other than the assigned school as an instrument for attending a choice school, find no evidence that choice is associated with increased educational attainment, with the exception of career academies. Lefgren (2002), exploiting differences in classroom peer quality that arise based on the extent of tracking, finds little or no benefit from attending a school with high-achieving peers.

Our findings present a mixed picture for the potential gains from school choice in urban districts. If the primary goal is to improve measures of academic achievement and attainment, then it does not appear that this mechanism is effective. The findings are consistent with an even stronger conclusion that attending "better" schools as measured by a variety of level measures of student performance does not systematically improve short-term academic outcomes. However, open enrollment in the CPS may confer other benefits that are equally worthy, including matching idiosyncratic tastes of parents and students and improving social circumstances. 


\section{References}

Altonji J.G., T. E. Elder, C. Taber (2002). “An Evaluation of Instrumental Variable Strategies for Estimating the Effect of Catholic Schools.” NBER \#9358.

Angrist, J., E. Bettinger, et.al (2002). "Vouchers for Private Schooling in Columbia: Evidence from a Randomized Natural Experiment”. American Economic Review. 92 (5):15351558.

Blank, R. K. (1983). Survey of Magnet Schools: Analyzing a Model of Quality Integrated Education. Washington, DC, ABT Associates for the Department of Education.

Bryk, A., V. Lee and P. Holland (1993). Catholic Schools and the Common Good. Cambridge, MA. Harvard University Press.

Coleman J.S., T. Hoffer and S. Kilgore (1982). High School Achievement: Public, Catholic and Private Schools Compared. New York: Basic Books.

Crain, R.L, A.L. Heebner and Y. Si (1992). The Effectiveness of New York City's Career Magnet Schools: An Evaluation of Ninth-Grade Performance Using an Experimental Design. Berkeley, CA, National Center for Research in Vocational Education.

Crain, R.L. and R. Thaler (1999). "Career Magnet Graduation Rates" in The Effects of Academic Career Magnet Education on High Schools and Their Graduates. Edited by Crain, et. al. National Center for Research in Vocational Education, University of California, Berkeley.

Cullen, J.B., B., Jacob and S. Levitt (forthcoming). "The Impact of School Choice on Student Outcomes: An Analysis of the Chicago Public Schools". Journal of Public Economics.

Dale, S.B. and A.Krueger (2002). "Estimating the Payoff to Attending a More Selective College: An Application of Selection on Observables and Unobservables”. Quarterly 
Journal of Economics 117 (4): 1491-1527.

Evans, William, and Robert Schwab (1995). "Finishing High School and Starting College: Do Catholic Schools Make a Difference?" Quarterly Journal of Economics 110 (4):941-974.

Figlio, D. and J. Ludwig (2000). Sex, Drugs and Catholic Schools: Private Schooling and NonMarket Adolescent Behaviors. NBER \#7990.

Gamoran, A. (1996). "Student Achievement in Public Magnet, Public Comprehensive, and Private City High Schools." Educational Evaluation and Policy Analysis 18 (1):1-18.

Hanushek, Eric A. (1997). “Assessing the Effects of School Resources on Student Performance:

An Update.” Educational Evaluation and Policy Analysis 19(2): 141-164.

Hanushek, E. A., J. F. Kain, J. M. Markman, and S. G. Rivkin. (2001). “Does Peer Ability Affect Student Achievement?” NBER Working Paper \#8502.

Hoxby, Caroline (2000). "Does Competition Among Public Schools Benefit Students and Taxpayers?" American Economic Review 90(5): 1209-1238.

Howell, William G. and Paul E. Peterson (2002). The Education Gap: Vouchers and Urban Schools. Washington, DC: Brookings Institution Press.

Katz, L., J. Kling, and J. Liebman (2001). "Moving to Opportunity in Boston: Early Results of a Randomized mobility Experiment". Quarterly Journal of Economics. 116 (2):607-654.

Kemple, J. J. and J. C. Snipes (2000). Career Academies' Impact on Students' Engagement and Performance in High School. Manpower Demonstration Research Corporation.

Krueger, Alan B. and Zhu, Pei (2003). "Another Look at the New York City School Voucher

Experiment.” National Bureau of Economic Research, Working Paper 9418.

Lee, David S. (2002). “Trimming for Bounds on Treatment Effects." National Bureau of Economic Research, Working Paper t0277. 
Lefgren, Lars (2002). "Educational Peer Effects and the Chicago Public Schools." Mimeo, Brigham Young University, Department of Economics.

Metz, M. H. (1986). Different by Design: The Context and Character of Three Magnet Schools. New York, Routledge Press.

Mocan, H.N., B. Scafidi, and E. Tekin (2002). "Catholic Schools and Bad Behavior.” NBER \#9172.

Neal, D. (1997). "The Effects of Catholic Secondary Schooling on Educational Achievement." Journal of Labor Economics, XV, 98-123.

Peterson, P.E., J. P Green., and J. Du (1997). The Effectiveness of School Choice: The Milwaukee Experiment. Cambridge, MA, Program on Education Policy and Governance, Harvard University.

Peterson, P. E., D. Myers and W. G. Howell (1998). An Evaluation of the New York City School Choice Scholarship Program: The First Year. Cambridge, MA, Mathematica Policy Research and the Harvard Program on Education Policy and Governance.

Peterson, Paul E (2002). “Victory for Vouchers?” Commentary. 114 (2): 46-51.

Rouse, C. E. (1998). "Private School Vouchers and Student Achievement: An Evaluation of the Milwaukee Parental Choice Program.” Quarterly Journal of Economics 113(2): 553-602.

Sander, W. (1996). "Catholic Grade Schools and Academic Achievement." Journal of Human Resources. 31(3): 540-48.

Witte, J.F., T.D. Sterr and C.A. Thorn (1995). Fifth-Year Report: Milwaukee Parental Choice Program. Madison, Wisconsin, University of Wisconsin.

Witte, J.F. (1997). Achievement Effects of the Milwaukee Voucher Program. American Economics Association Annual Meeting, New Orleans. 


\section{Appendix A: Sample and Data Sources}

CPS provided information on applications submitted in the spring 2000 and spring 2001. The sample of applications provided to us for eighth-grade applicants enrolled in CPS at the time of application includes 59,962 applications to 45 choice high schools. Approximately one-third as many applications are submitted to the selective enrollment high schools that do not use lotteries in admissions, none of which are included in our analysis. Although CPS has information on the applications submitted to 45 schools, it only tracks lottery outcomes for the 27 high schools for which the district manages the lottery process. There are a variety of idiosyncratic reasons why CPS manages the lottery for some high schools, and these schools are not systematically different from the schools that manage their own.

There are a total of 26,805 applications from 17,582 students for which we have lottery outcomes. Of the 375 lotteries represented by these lotteries, 10 lotteries have no winners and 171 have no losers. Lotteries that are not oversubscribed will not have any losers. A lottery will not have any winners if parents mistakenly submitted an application to a school-program-grade that was not accepting any students in a given year (because of space constraints) or if changing enrollment numbers led schools to not accept new students, even though application brochures had indicated that the school would have open slots. Since we cannot estimate any treatment effects from these degenerate lotteries, we exclude these from our analysis. Restricting our attention to lotteries that have winners and losers, our analysis sample includes 19,520 applications from 14,434 students participating in 194 lotteries at 19 different high schools.

Our school-level and student-level data come from a variety of sources described in Table A1 below. 
Table A1: Data sources and variable construction

\begin{tabular}{|c|c|c|}
\hline Data & Source & Construction \\
\hline $\begin{array}{l}\text { Academic } \\
\text { Outcomes }\end{array}$ & CPS Board & $\begin{array}{l}\text { Standardized test scores, grades, absences, credits and course } \\
\text { taking outcomes are taken directly from student test and } \\
\text { transcript files provided by the Board. Information on } \\
\text { enrollment and exit status/reason is from administrative } \\
\text { records provided by the Board. Various fields in these data } \\
\text { allow us to determine the reason why a student has exited (is } \\
\text { not enrolled in) the public school system, including moved } \\
\text { out of the district, transferred to private school, graduated, } \\
\text { dropped out, etc. } 9^{\text {th }} \text { and } 10^{\text {th }} \text { grade reading scores come from } \\
\text { the Test of Academic Proficiency (TAP), a nationally-normed } \\
\text { standardized achievement exam published by Riverside, and } \\
\text { are measured in terms of national percentile rank. The end- } \\
\text { of-course exams (algebra, geometry, English I, English II) } \\
\text { were developed specifically to coincide with the Chicago high } \\
\text { school curriculum, and consisted of multiple-choice as well as } \\
\text { open-response items. We use only the multiple-choice items, } \\
\text { which were graded electronically by a scanning machine. } \\
\text { The test score is measured as a fraction of the items answered } \\
\text { correctly. Absences are defined as the average number of } \\
\text { days absent across courses for the Spring semester of a given } \\
\text { year. Total credits are defined as the sum of all credits earned } \\
\text { in the Spring semester of a given year (students receive } \\
\text { credits if they do not fail the course - i.e., earn any grade } \\
\text { above F). }\end{array}$ \\
\hline $\begin{array}{l}\text { Non-Traditional } \\
\text { Outcomes }\end{array}$ & CCSR & $\begin{array}{l}\text { The Consortium on Chicago School Research (CCSR) } \\
\text { administered a survey to CPS students in grades 6-10 in } \\
\text { Spring of 2001, which asked students a variety of questions } \\
\text { about their teachers, schools and peers as well as about their } \\
\text { own attitudes and behaviors relating to school. Several of the } \\
\text { survey outcomes we use are composite measures created by } \\
\text { CCSR from student responses to a collection of individual } \\
\text { items (see the notes associated with Table 7). Greater detail } \\
\text { on the construction of these items is available from CCSR. }\end{array}$ \\
\hline $\begin{array}{l}\text { Student } \\
\text { Demographics }\end{array}$ & CPS Board & $\begin{array}{l}\text { Student demographic variables (race, gender, age) come } \\
\text { directly from student records provided by the Board. All of } \\
\text { the demographics are based on status as of } 8^{\text {th }} \text { grade. Special } \\
\text { education status covers a variety of disabilities ranging from } \\
\text { mild learning disabilities to severe physical handicaps. } 7^{\text {th }} \\
\text { and } 8^{\text {th }} \text { grade achievement scores come from the Iowa Test of } \\
\text { Basic Skills, a nationally-normed standardized achievement } \\
\text { exam published by Riverside, and are measured in terms of } \\
\text { the student's national percentile rank. }\end{array}$ \\
\hline $\begin{array}{l}\text { Neighborhood } \\
\text { Characteristics }\end{array}$ & $\begin{array}{l}2000 \\
\text { Census \& }\end{array}$ & $\begin{array}{l}\text { Basic information on the student's census tract, such as } \\
\text { median household income and percent below the poverty line, }\end{array}$ \\
\hline
\end{tabular}




\begin{tabular}{|lll|}
\hline & $\begin{array}{l}\text { CPS Board } \\
\text { \& CCSR }\end{array}$ & $\begin{array}{l}\text { comes from the 2000 Census. Student census tract was } \\
\text { determined on the basis of student address, which is contained } \\
\text { in the CPS school records. The crime composite is an index } \\
\text { created by factor analysis using official crime statistics for } \\
\text { 1994 provided by the Consortium on Chicago School } \\
\text { Research (CCSR). The index was created at the block group } \\
\text { level. The variable used in this analysis is a tract-level } \\
\text { average (for the student's tract in the Spring of } 8^{\text {th }} \text { grade), } \\
\text { weighted by the total population in each block group. }\end{array}$ \\
& & \\
\hline $\begin{array}{l}\text { Distance from } \\
\text { home to school }\end{array}$ & CPS Board & $\begin{array}{l}\text { Student and school census tracts were determined based on } \\
\text { address information provided in CPS records. Distance from } \\
\text { home to school was calculated as the distance from the } \\
\text { centroid of home tract to the centroid of school tract. }\end{array}$ \\
\hline
\end{tabular}




\section{Appendix B: Testing for Attrition Bias}

Although we have demonstrated that there is little evidence of selective attrition at the point of enrollment in $9^{\text {th }}$ grade (see the discussion in the text and Table 4), there are other points at which students can be absent from our sample. Outcome data in the springs of the first and second years may be missing if a student has dropped out or does not attend on the day of the exam. Thus, if winning a lottery has positive (negative) attainment and attendance effects, winners may be more (less) likely to continue in our sample. Table B1 provides information on the rates at which outcome data are missing in $9^{\text {th }}$ and $10^{\text {th }}$ grade, and whether winners and losers with outcome information are systematically different according to predetermined characteristics. Even when data are missing at statistically significantly different rates for winners and losers, the differences in these rates are not large in practical terms. Further, winners and losers with outcome information continue to appear comparable along important observable dimensions.

The fact that differential attrition over the first two years of high school is not great is further evidence that winning does not confer attainment gains. An interesting exception is the finding that winners of lotteries to high-achieving schools are significantly less likely to be missing English II scores in $10^{\text {th }}$ grade (but not TAP reading scores), which implies that they are more likely to take this course. We have found that this apparent course-taking effect is greatest for Hispanic students, implying that lottery losers with limited English proficiency might be taking less rigorous courses.

To further support the proposition that selective attrition is unlikely to introduce much bias to our estimates, Table B2 examines the sensitivity of our results to a variety of possible sample selection correction methodologies. We present results only for ninth grade reading 
scores; other outcome variables yield similar results. In all cases, other than when we construct worst-case bounds, we can rule out effects of winning the lottery that are of any meaningful magnitude.

Table B1: Additional evidence on sample attrition

\begin{tabular}{lccccc}
\hline \multicolumn{7}{c}{ Panel $\boldsymbol{A}-$ Outcome Attrition in $\mathbf{9}^{\text {th }} \mathbf{G r a d e}$} \\
& $\begin{array}{c}\text { Missing } \\
\text { Any } \\
\text { Outcome } \\
\text { Data }\end{array}$ & $\begin{array}{c}\text { Missing } \\
\text { Trans. } \\
\text { Data }\end{array}$ & $\begin{array}{c}\text { Missing } \\
\text { Read } \\
\text { Score }\end{array}$ & $\begin{array}{c}\text { Missing } \\
\text { Algebra } \\
\text { Score }\end{array}$ & $\begin{array}{c}\text { Missing } \\
\text { English I } \\
\text { Score }\end{array}$ \\
& -0.044 & -0.005 & -0.001 & -0.025 & -0.029 \\
Win lottery to high-achieving & $(0.019)$ & $(0.010)$ & $(0.013)$ & $(0.018)$ & $(0.017)$ \\
school & {$[0.305]$} & {$[0.060]$} & {$[0.106]$} & {$[0.225]$} & {$[0.204]$} \\
& -0.010 & -0.014 & -0.001 & -0.008 & -0.010 \\
Win lottery to other choice school & $(0.015)$ & $(0.008)$ & $(0.011)$ & $(0.014)$ & $(0.014)$ \\
& {$[0.383]$} & {$[0.072]$} & {$[0.166]$} & {$[0.289]$} & {$[0.272]$} \\
\hline Number of observations & 17,470 & 17,470 & 17,470 & 17,470 & 17,470 \\
Sample limited to those who are & & & & & \\
enrolled in $9^{\text {th }}$ grade in the CPS in & Yes & Yes & Yes & Yes & Yes \\
the Fall & & & & & \\
\hline
\end{tabular}

Panel B - Is Outcome Attrition in $9^{\text {th }}$ Grade Selective?

\begin{tabular}{|c|c|c|c|c|c|}
\hline & $\begin{array}{l}8^{\text {th }} \text { Grade } \\
\text { Reading }\end{array}$ & $\begin{array}{c}8^{\text {th }} \text { Grade } \\
\text { Math }\end{array}$ & $\begin{array}{l}\text { Free or } \\
\text { reduced } \\
\text { priced } \\
\text { lunch }\end{array}$ & $\begin{array}{l}\text { Special } \\
\text { Educ. }\end{array}$ & $\begin{array}{l}\text { Tract Pov. } \\
\text { Rate }\end{array}$ \\
\hline $\begin{array}{l}\text { Win lottery to high-achieving } \\
\text { school }\end{array}$ & $\begin{array}{c}-0.004 \\
(0.011) \\
{[0.554]} \\
-0.004 \\
(0.008) \\
{[0.448]} \\
\end{array}$ & $\begin{array}{c}0.007 \\
(0.011) \\
{[0.602]} \\
-0.008 \\
(0.009) \\
{[0.496]}\end{array}$ & $\begin{array}{c}0.012 \\
(0.018) \\
{[0.792]} \\
0.002 \\
(0.013) \\
{[0.899]} \\
\end{array}$ & $\begin{array}{c}0.011 \\
(0.012) \\
{[0.067]} \\
0.005 \\
(0.012) \\
{[0.095]}\end{array}$ & $\begin{array}{c}-0.003 \\
(0.006) \\
{[0.206]} \\
0.005 \\
(0.004) \\
{[0.237]} \\
\end{array}$ \\
\hline Number of observations & 11,389 & 11,396 & 11,462 & 11,462 & 11,452 \\
\hline $\begin{array}{l}\text { Sample limited to those who have } \\
\text { outcome data (all samples } \\
\text { conditional on enrollment in the } \\
9^{\text {th }} \text { grade in the CPS in the Fall) }\end{array}$ & Yes & Yes & Yes & Yes & Yes \\
\hline
\end{tabular}
Panel C-Survey Attrition ${ }^{\text {a }}$

\begin{tabular}{lcccccc} 
& $\begin{array}{c}\text { Took } \\
\text { Survey }\end{array}$ & $\begin{array}{c}8^{\text {th }} \text { Grade } \\
\text { Reading }\end{array}$ & $\begin{array}{c}8^{\text {th }} \text { Grade } \\
\text { Math }\end{array}$ & $\begin{array}{c}\text { Free or } \\
\text { reduced } \\
\text { price } \\
\text { lunch }\end{array}$ & $\begin{array}{c}\text { Special } \\
\text { Educ. }\end{array}$ & $\begin{array}{c}\text { Tract Pov. } \\
\text { Rate }\end{array}$ \\
\hline $\begin{array}{l}\text { Win lottery to high-achieving } \\
\text { school }\end{array}$ & -0.010 & -0.015 & -0.014 & -0.020 & 0.027 & -0.012 \\
& $(0.032)$ & $(0.018)$ & $(0.019)$ & $(0.026)$ & $(0.022)$ & $(0.009)$ \\
& {$[0.612]$} & {$[0.560]$} & {$[0.629]$} & {$[0.835]$} & {$[0.053]$} & {$[0.228]$}
\end{tabular}




\begin{tabular}{|c|c|c|c|c|c|c|}
\hline Win lottery to other choice school & $\begin{array}{c}0.091 \\
(0.023) \\
{[0.542]}\end{array}$ & $\begin{array}{c}-0.004 \\
(0.013) \\
{[0.438]}\end{array}$ & $\begin{array}{l}-0.002 \\
(0.014) \\
{[0.499]}\end{array}$ & $\begin{array}{c}0.020 \\
(0.019) \\
{[0.899]}\end{array}$ & $\begin{array}{l}-0.002 \\
(0.019) \\
{[0.107]}\end{array}$ & $\begin{array}{c}0.003 \\
(0.006) \\
{[0.232]}\end{array}$ \\
\hline Number of observations & 5,234 & 2,926 & 2,926 & 3,015 & 3,015 & 3,013 \\
\hline $\begin{array}{l}\text { Sample limited to those who took } \\
\text { survey (all samples conditional on } \\
\text { enrollment in the } 9^{\text {th }} \text { grade in the } \\
\text { CPS in the Fall) }\end{array}$ & No & Yes & Yes & Yes & Yes & Yes \\
\hline
\end{tabular}

Panel D - Outcome Attrition in $10^{\text {th }}$ Grade (2000 Cohort Only)

\begin{tabular}{lccccc} 
& $\begin{array}{c}\text { Missing } \\
\text { Any } \\
\text { Outcome } \\
\text { Data }\end{array}$ & $\begin{array}{c}\text { Missing } \\
\text { Trans. } \\
\text { Data }\end{array}$ & $\begin{array}{c}\text { Missing } \\
\text { Read } \\
\text { Score }\end{array}$ & $\begin{array}{c}\text { Missing } \\
\text { Geometry } \\
\text { Score }\end{array}$ & $\begin{array}{c}\text { Missing } \\
\text { English II } \\
\text { Score }\end{array}$ \\
\hline Win lottery to high-achieving & 0.009 & -0.008 & -0.016 & 0.039 & -0.068 \\
school & $(0.031)$ & $(0.009)$ & $(0.020)$ & $(0.029)$ & $(0.022)$ \\
& {$[0.389]$} & {$[0.028]$} & {$[0.135]$} & {$[0.218]$} & {$[0.174]$} \\
Win lottery to other choice school & -0.026 & -0.012 & -0.002 & -0.022 & 0.014 \\
& $(0.024)$ & $(0.009)$ & $(0.019)$ & $(0.021)$ & $(0.021)$ \\
\hline $\begin{array}{l}\text { Number of observations } \\
\text { Sample limited to those who are }\end{array}$ & $7,434]$ & {$[0.035]$} & {$[0.206]$} & {$[0.251]$} & {$[0.218]$} \\
$\begin{array}{l}\text { enrolled in the CPS in the Spring } \\
\text { of } 10^{\text {th }} \text { grade }\end{array}$ & Yes & 7,471 & 7,471 & 7,471 & 7,471 \\
\hline
\end{tabular}

Panel E-Is Outcome Attrition in $10^{\text {th }}$ Grade Selective? (2000 Cohort only)

\begin{tabular}{|c|c|c|c|c|c|}
\hline & $\begin{array}{l}8^{\text {th }} \text { Grade } \\
\text { Reading }\end{array}$ & $\begin{array}{l}8^{\text {th }} \text { Grade } \\
\text { Math }\end{array}$ & $\begin{array}{l}\text { Free or } \\
\text { reduced } \\
\text { priced } \\
\text { lunch }\end{array}$ & $\begin{array}{l}\text { Special } \\
\text { Educ. }\end{array}$ & $\begin{array}{l}\text { Tract Pov. } \\
\text { Rate }\end{array}$ \\
\hline $\begin{array}{l}\text { Win lottery to high-achieving } \\
\text { school }\end{array}$ & $\begin{array}{c}0.013 \\
(0.016) \\
{[0.5563]} \\
0.003 \\
(0.013) \\
{[0.449]} \\
\end{array}$ & $\begin{array}{c}0.014 \\
(0.015) \\
{[0.631]} \\
-0.003 \\
(0.014) \\
{[0.514]} \\
\end{array}$ & $\begin{array}{c}0.002 \\
(0.034) \\
{[0.682]} \\
-0.011 \\
(0.026) \\
{[0.811]} \\
\end{array}$ & $\begin{array}{l}-0.003 \\
(0.017) \\
{[0.058]} \\
-0.009 \\
(0.017) \\
{[0.095]} \\
\end{array}$ & $\begin{array}{c}-0.012 \\
(0.009) \\
{[0.198]} \\
0.004 \\
(0.006) \\
{[0.231]} \\
\end{array}$ \\
\hline Number of observations & 4,747 & 4,744 & 4,783 & 4,783 & 4,780 \\
\hline $\begin{array}{l}\text { Sample limited to those who have } \\
\text { outcome data (all samples } \\
\text { conditional on enrollment in the } \\
\text { CPS in the Spring of } 10^{\text {th }} \text { grade) }\end{array}$ & Yes & Yes & Yes & Yes & Yes \\
\hline
\end{tabular}

Notes: All regression estimates include a set of lottery fixed effects, but no other covariates. Eiker-White robust standard errors adjusted to account for the correlation of errors across applications within a single student are shown in parentheses. Control group means (i.e., the means for students who lost these lotteries) are shown in square brackets. ${ }^{\mathrm{a}}$ The sample in Panel $\mathrm{C}$ includes only students in the 2000 cohort and excludes students who applied to three schools (Von Steuben, Roosevelt and Lake View) that did not administer the survey. 


\title{
Table B2: Sensitivity of reduced form reading score estimates to alternative selection corrections
}

\author{
The effect of winning a lottery to a $\ldots$ \\ High-Achieving \\ School \\ Other Choice School
}

\begin{tabular}{|c|c|c|}
\hline Baseline Estimates & $\begin{array}{c}-0.010 \\
(0.007)\end{array}$ & $\begin{array}{l}-0.013 \\
(0.005)\end{array}$ \\
\hline \multicolumn{3}{|l|}{ Generic Bounding } \\
\hline $\begin{array}{l}\text { Assign students with missing outcome data a score equivalent to the } \\
10^{\text {th }} \text { percentile of the sample, regardless of whether the student won } \\
\text { or lost the lottery. }\end{array}$ & $\begin{array}{c}0.002 \\
(0.008)\end{array}$ & $\begin{array}{c}-0.006 \\
(0.005)\end{array}$ \\
\hline Assume a score comparable to the $25^{\text {th }}$ percentile & $\begin{array}{c}-0.003 \\
(0.007)\end{array}$ & $\begin{array}{c}-0.007 \\
(0.004)\end{array}$ \\
\hline Assume a score comparable to $75^{\text {th }}$ percentile & $\begin{array}{l}-0.016 \\
(0.007)\end{array}$ & $\begin{array}{l}-0.011 \\
(0.005)\end{array}$ \\
\hline Assume a score comparable to $90^{\text {th }}$ percentile & $\begin{array}{c}-0.022 \\
(0.008)\end{array}$ & $\begin{array}{l}-0.013 \\
(0.007)\end{array}$ \\
\hline $\begin{array}{l}\text { Assign students with missing outcome data a score equivalent to } \\
\text { what they would have scored if they had made gains comparable to } \\
\text { the } 10^{\text {th }} \text { percentile of the sample, regardless of whether the student } \\
\text { won or lost the lottery. }\end{array}$ & $\begin{array}{c}0.000 \\
(0.007)\end{array}$ & $\begin{array}{c}-0.009 \\
(0.005)\end{array}$ \\
\hline Assume gains comparable to the $25^{\text {th }}$ percentile & $\begin{array}{c}-0.004 \\
(0.006)\end{array}$ & $\begin{array}{c}-0.010 \\
(0.004)\end{array}$ \\
\hline Assume gains comparable to the $75^{\text {th }}$ percentile & $\begin{array}{c}-0.013 \\
(0.006)\end{array}$ & $\begin{array}{c}-0.013 \\
(0.004)\end{array}$ \\
\hline Assume gains comparable to the $90^{\text {th }}$ percentile & $\begin{array}{c}-0.016 \\
(0.007) \\
\end{array}$ & $\begin{array}{c}-0.014 \\
(0.005) \\
\end{array}$ \\
\hline \multicolumn{3}{|l|}{ Lee's Trimming Method (Lee 2002) } \\
\hline $\begin{array}{l}\text { Trim the worst } \mathrm{X} \% \text { of winners in lotteries where } \mathrm{X} \% \text { more losers } \\
\text { are missing outcome data (if } \mathrm{X}<0 \text {, do nothing). This assumes that, } \\
\text { among those who lose the lottery, the lowest-achieving students } \\
\text { will leave the system. }\end{array}$ & $\begin{array}{c}-0.005 \\
(0.007)\end{array}$ & $\begin{array}{l}-0.007 \\
(0.005)\end{array}$ \\
\hline $\begin{array}{l}\text { Trim the best X\% of winners. This assumes that, among those who } \\
\text { lose the lottery, the highest-achieving students will leave the } \\
\text { system. }\end{array}$ & $\begin{array}{c}-0.022 \\
(0.007)\end{array}$ & $\begin{array}{c}-0.022 \\
(0.005)\end{array}$ \\
\hline
\end{tabular}

\section{Control Function Method}

Includes a cubic in the percentage point difference in the enrollment rate between winners and losers in a particular lottery along with interactions between these measures and an indicator for whether the student won the lottery. $\mathrm{D}=$ mean enrollment rate among losers - mean enrollment rate among winners. $S=$ indicates whether the student won the lottery. Control function variables include $\mathrm{D}, \mathrm{D}^{\wedge} 2$, $\mathrm{D}^{\wedge} 3, \mathrm{~S}^{*} \mathrm{D}, \mathrm{S}^{*} \mathrm{D}^{\wedge} 2, \mathrm{~S}^{*} \mathrm{D}^{\wedge} 3$. Because $\mathrm{D}$ is the difference and we want to evaluate the function at zero, we can simply read the coefficient on the main effect for $\mathrm{S}$.

Same as above except that we allow the $D$ and $S * D$ variables to vary across good and other lotteries (basically the same as running these applications differently).

$-0.016 \quad-0.011$

$(0.009) \quad(0.006)$

\section{Heckman Selection Model}

Instrument: Distance from home to application school (F-stat $=9.06$

for predicting $9^{\text {th }}$ grade enrollment but only 3.61 for predicting missing reading score in $9^{\text {th }}$ grade) 
tract who are enrolled in private schools $(\mathrm{F}$-stat $=5.76$ for

(0.009)

$(0.006)$

predicting $9^{\text {th }}$ grade enrollment but only 1.44 for predicting missing

reading score in $9^{\text {th }}$ grade)

\section{Worst Case Bounding}

For students with missing outcome data who lost the lottery, assume that the student would have made gains comparable to the bottom

$10^{\text {th }}$ percentile of the sample. For students with missing outcome data who won the lottery, assume that the student would have made gains comparable to the top $10^{\text {th }}$ percentile of the sample.

Vice versa

Missing losers set to bottom $10 \%$ of scores and missing winners set

Notes: Lee's method requires an assumption of monotonicity, which may not hold in our context. Our implementation assumes that winning a lottery can only make an individual more likely to have non-missing outcome data. For more detail on the methodology, see Lee (2002). 
Appendix C: The impact of winning a lottery on non-traditional measures of student outcomes by student characteristic

\begin{tabular}{|c|c|c|c|c|c|c|c|}
\hline \multicolumn{8}{|c|}{ The effect of winning a lottery to a high-achieving school for the following subgroups of students... } \\
\hline Dependent Variable & $\begin{array}{l}\text { All students (i.e., } \\
\text { those applying to } \\
\text { high-achieving } \\
\text { school }) \\
(n=8,448)\end{array}$ & $\begin{array}{c}\text { Black } \\
(n=3,568)\end{array}$ & $\begin{array}{l}\text { Hispanic } \\
(n=3,146)\end{array}$ & $\begin{array}{c}\text { Male } \\
(n=3,512)\end{array}$ & $\begin{array}{l}\text { Below average } 8^{\text {th }} \\
\text { grade test scores } \\
(n=3,284)\end{array}$ & $\begin{array}{l}\text { Home-School } \\
\text { Distance } \\
>2 \text { miles } \\
(n=4,143)\end{array}$ & $\begin{array}{c}\text { Alternative school } \\
\text { has scores below } \\
\text { national norms } \\
(\mathrm{n}=4,735)\end{array}$ \\
\hline Likes school & $\begin{array}{c}0.148 \\
(0.125) \\
{[4.14]}\end{array}$ & $\begin{array}{c}0.365 \\
(0.333) \\
{[3.96]}\end{array}$ & $\begin{array}{c}0.143 \\
(0.135) \\
{[4.36]}\end{array}$ & $\begin{array}{c}-0.150 \\
(0.254) \\
{[3.90]}\end{array}$ & $\begin{array}{c}-0.348 \\
(0.299) \\
{[4.35]}\end{array}$ & $\begin{array}{c}0.284 * \\
(0.150) \\
{[4.09]}\end{array}$ & $\begin{array}{c}-0.084 \\
(0.175) \\
{[4.28]}\end{array}$ \\
\hline $\begin{array}{l}\text { Arrested by police in past } \\
\text { year }\end{array}$ & $\begin{array}{c}-0.050 * * \\
(0.024) \\
{[0.089]}\end{array}$ & $\begin{array}{l}-0.038 \\
(0.054) \\
{[0.086]}\end{array}$ & $\begin{array}{c}-0.054 * * \\
(0.025) \\
{[0.094]}\end{array}$ & $\begin{array}{l}-0.070 * \\
(0.042) \\
{[0.129]}\end{array}$ & $\begin{array}{l}0.038 \\
(0.072) \\
{[0.115]}\end{array}$ & $\begin{array}{l}-0.037 \\
(0.026) \\
{[0.073]}\end{array}$ & $\begin{array}{l}-0.022 \\
(0.031) \\
{[0.087]}\end{array}$ \\
\hline $\begin{array}{l}\text { School has enough } \\
\text { computers }\end{array}$ & $\begin{array}{l}0.119 * * \\
(0.030) \\
{[0.643]}\end{array}$ & $\begin{array}{l}0.183 * * \\
(0.076) \\
{[0.669]}\end{array}$ & $\begin{array}{l}0.089 * * \\
(0.028) \\
{[0.611]}\end{array}$ & $\begin{array}{l}0.256 * * \\
(0.056) \\
{[0.610]}\end{array}$ & $\begin{array}{l}0.058 \\
(0.068) \\
{[0.629]}\end{array}$ & $\begin{array}{l}0.137 * * \\
(0.057) \\
{[0.664]}\end{array}$ & $\begin{array}{l}0.116 * * \\
(0.039) \\
{[0.633]}\end{array}$ \\
\hline
\end{tabular}

Notes: The specifications here mirror those shown for the traditional outcome measures in Table 8. 
Table 1. Chicago public high schools represented in the analysis

\begin{tabular}{|c|c|c|c|c|c|c|c|}
\hline School Name & $\begin{array}{l}\text { Achievement Rank } \\
\text { (percentile) } \\
\text { Among CPS High } \\
\text { Schools }\end{array}$ & $\begin{array}{c}\text { Number of } \\
\text { Analysis Lotteries }\end{array}$ & $\begin{array}{l}\text { Number of } \\
\text { Lottery } \\
\text { Participants }\end{array}$ & $\begin{array}{l}\text { Percentage of } \\
\text { Participants } \\
\text { Selected }\end{array}$ & $\begin{array}{l}\text { Percentage of } \\
\text { Winners Enrolling } \\
\text { in the School }\end{array}$ & $\begin{array}{c}\text { Percentage of } \\
\text { Students Black or } \\
\text { Hispanic }\end{array}$ & $\begin{array}{c}\text { Percentage of } \\
\text { Students } \\
\text { Receiving Special } \\
\text { Education }\end{array}$ \\
\hline$(1)$ & $(2)$ & (3) & (4) & $(5)$ & $(6)$ & $(7)$ & $(8)$ \\
\hline Chicago Agricultural & 90.0 & 9 & 627 & 17.7 & 53.6 & 73.7 & 12.4 \\
\hline Von Steuben & 89.8 & 15 & 5,888 & 2.9 & 49.4 & 44.5 & 10.2 \\
\hline Curie Metro & 78.7 & 56 & 898 & 18.7 & 64.7 & 78.1 & 14.2 \\
\hline Hyde Park Academy & 75.3 & 5 & 1,243 & 9.1 & 41.1 & 99.4 & 18.7 \\
\hline Kennedy & 74.6 & 7 & 817 & 29.2 & 28.2 & 55.9 & 20.0 \\
\hline George Washington & 72.4 & 5 & 355 & 53.0 & 18.6 & 85.9 & 21.2 \\
\hline Taft & 72.3 & 16 & 1,881 & 27.7 & 22.8 & 53.4 & 17.7 \\
\hline Lake View & 70.9 & 9 & 144 & 35.1 & 6.0 & 77.8 & 15.9 \\
\hline Bogan Tech & 66.1 & 12 & 3,289 & 15.3 & 38.7 & 86.3 & 20.3 \\
\hline Amundsen & 59.3 & 6 & 522 & 5.4 & 42.9 & 60.8 & 18.7 \\
\hline Senn & 46.2 & 11 & 831 & 18.4 & 14.7 & 75.0 & 20.4 \\
\hline Juarez & 45.0 & 5 & 241 & 19.5 & 12.8 & 97.2 & 18.4 \\
\hline Roosevelt & 39.4 & 16 & 860 & 13.8 & 13.8 & 69.9 & 21.6 \\
\hline Wells & 35.4 & 7 & 654 & 39.8 & 24.7 & 92.4 & 23.3 \\
\hline Hirsch Metro & 31.4 & 2 & 240 & 52.1 & 32.0 & 100.0 & 20.4 \\
\hline Corliss & 24.8 & 2 & 365 & 43.3 & 25.9 & 99.9 & 30.7 \\
\hline Robeson & 10.0 & 2 & 131 & 24.4 & 9.4 & 99.8 & 29.4 \\
\hline Harper & 6.2 & 7 & 366 & 10.5 & 8.6 & 100.0 & 28.0 \\
\hline Orr & 2.5 & 2 & 168 & 18.5 & 22.6 & 99.6 & 27.7 \\
\hline
\end{tabular}

Notes: These summary statistics are based on the combined 2000 and 2001 applications. Student achievement is measured as composite $8^{\text {th }}$ grade math and reading scores (expressed as national percentile ranks) among $9^{\text {th }}$ graders in the school. The school's achievement rank is calculated as its percentile in the distribution of regular (i.e. non-alternative) high schools, where the distribution is weighted by $9^{\text {th }}$ grade enrollment at each high school. The values in columns 3 and 4 are totals across the two years. The values in columns 2 and 5-8 are weighted averages of the 2000 and 2001 values, where the weights are proportional to the number of applications received by the school in those years. The schools that are shaded are classified as high-achieving schools. 
Table 2. Comparison of lottery participants to other CPS $8^{\text {th }}$ graders

\begin{tabular}{lcccc}
\hline \multicolumn{1}{c}{ Student Characteristic } & $\begin{array}{c}\text { Lottery } \\
\text { Participants } \\
(1)\end{array}$ & $\begin{array}{c}\text { Other Students } \\
(2)\end{array}$ & $\begin{array}{c}\text { Difference } \\
(1)-(2)\end{array}$ & $\begin{array}{c}\text { Standard Error } \\
\text { of Difference }\end{array}$ \\
\hline White & 0.119 & 0.109 & 0.010 & 0.003 \\
Black & 0.460 & 0.535 & -0.075 & 0.005 \\
Hispanic & 0.370 & 0.326 & 0.043 & 0.004 \\
Male & 0.423 & 0.531 & -0.107 & 0.005 \\
$8^{\text {th }}$ gr. math national percentile score & 0.526 & 0.425 & 0.101 & 0.003 \\
$8^{\text {th }}$ gr. reading national percentile score & 0.485 & 0.401 & 0.083 & 0.002 \\
Free lunch eligible & 0.725 & 0.752 & -0.027 & 0.004 \\
Receiving special education & 0.116 & 0.220 & -0.104 & 0.004 \\
Ever received bilingual education & 0.432 & 0.352 & 0.080 & 0.005 \\
Living with a biological parent & 0.800 & 0.794 & 0.006 & 0.004 \\
Tract poverty rate & 0.218 & 0.248 & -0.029 & 0.001 \\
Tract fraction HS graduates & 0.646 & 0.639 & 0.007 & 0.001 \\
\hline
\end{tabular}

Notes: The unit of observation is the student. There are 14,434 students participating in at least one of the lotteries included in our analysis. Mean characteristics for lottery participants are shown in column 1 . There are 46,748 other $8^{\text {th }}$ graders enrolled in CPS in Spring 2000 and Spring 2001. Mean characteristics for these students are shown in column 2. Alternative schools include special education schools, juvenile detention centers, and alternative education programs for pregnant girls. 
Table 3. The validity of the lotteries

\begin{tabular}{|c|c|c|}
\hline \multirow{2}{*}{ Dependent Variable } & \multicolumn{2}{|c|}{ The effect of winning a lottery to ... } \\
\hline & High-Achieving School & Other Choice School \\
\hline \multicolumn{3}{|c|}{$\begin{array}{c}\text { Student's characteristics at time of } \\
\text { application }\end{array}$} \\
\hline \multirow[t]{3}{*}{ Math percentile score } & 0.011 & -0.006 \\
\hline & $(0.009)$ & $(0.007)$ \\
\hline & {$[0.578]$} & {$[0.456]$} \\
\hline \multirow[t]{3}{*}{ Reading percentile score } & 0.000 & -0.005 \\
\hline & $(0.009)$ & $(0.006)$ \\
\hline & {$[0.535]$} & {$[0.417]$} \\
\hline \multirow[t]{3}{*}{ Age } & 0.02 & -0.00 \\
\hline & $(0.02)$ & $(0.01)$ \\
\hline & {$[13.92]$} & [13.99] \\
\hline \multirow[t]{3}{*}{ Free lunch eligible } & 0.025 & -0.005 \\
\hline & $(0.017)$ & $(0.012)$ \\
\hline & {$[0.667]$} & {$[0.808]$} \\
\hline \multirow[t]{3}{*}{ Reduced-price lunch eligible } & -0.011 & 0.006 \\
\hline & $(0.013)$ & $(0.008)$ \\
\hline & {$[0.121]$} & {$[0.091]$} \\
\hline \multirow[t]{3}{*}{ Receiving special education } & 0.006 & 0.011 \\
\hline & $(0.013)$ & $(0.010)$ \\
\hline & {$[0.100]$} & {$[0.133]$} \\
\hline \multirow[t]{3}{*}{ Ever received bilingual education } & 0.007 & -0.011 \\
\hline & $(0.015)$ & $(0.009)$ \\
\hline & {$[0.497]$} & {$[0.404]$} \\
\hline \multirow[t]{3}{*}{ Living with a biological parent } & 0.016 & -0.010 \\
\hline & $(0.016)$ & $(0.011)$ \\
\hline & {$[0.785]$} & {$[0.814]$} \\
\hline \multirow[t]{3}{*}{ Attends assigned $8^{\text {th }}$ grade school } & 0.012 & 0.001 \\
\hline & $(0.019)$ & $(0.014)$ \\
\hline & {$[0.589]$} & {$[0.644]$} \\
\hline \multirow[t]{3}{*}{ Number of applications submitted } & 0.01 & -0.00 \\
\hline & $(0.07)$ & $(0.06)$ \\
\hline & {$[3.01]$} & [3.82] \\
\hline \multicolumn{3}{|c|}{$\begin{array}{l}\text { School and neighborhood characteristics at } \\
\text { time of application }\end{array}$} \\
\hline \multirow[t]{3}{*}{ Mean achievement level in school } & $0.010^{*}$ & -0.001 \\
\hline & $(0.006)$ & $(0.004)$ \\
\hline & {$[0.467]$} & {$[0.384]$} \\
\hline \multirow[t]{3}{*}{ Fraction transferring into school } & -0.010 & -0.002 \\
\hline & $(0.013)$ & $(0.008)$ \\
\hline & {$[0.355]$} & {$[0.305]$} \\
\hline \multirow[t]{3}{*}{ Tract fraction Black } & -0.004 & 0.006 \\
\hline & $(0.008)$ & $(0.006)$ \\
\hline & {$[0.357]$} & {$[0.497]$} \\
\hline \multirow[t]{3}{*}{ Tract fraction Hispanic } & -0.002 & -0.005 \\
\hline & $(0.008)$ & $(0.006)$ \\
\hline & {$[0.319]$} & {$[0.319]$} \\
\hline \multirow[t]{3}{*}{ Tract poverty rate } & -0.002 & 0.003 \\
\hline & $(0.005)$ & $(0.003)$ \\
\hline & {$[0.207]$} & {$[0.238]$} \\
\hline \multirow[t]{3}{*}{ Tract fraction HS graduates } & 0.002 & 0.001 \\
\hline & $(0.005)$ & $(0.003)$ \\
\hline & [0.662] & {$[0.630]$} \\
\hline
\end{tabular}


Tract fraction homeowners

Tract fraction not-in-the-labor force

Tract crime index

Tract fraction in private high schools

$\begin{array}{cc}0.018^{* *} & -0.001 \\ (0.008) & (0.005) \\ {[0.422]} & {[0.416]} \\ 0.000 & 0.003 \\ (0.003) & (0.002) \\ {[0.403]} & {[0.422]} \\ 0.008 & 0.015 \\ (0.022) & (0.014) \\ {[-0.115]} & {[0.074]} \\ 0.009 & -0.002 \\ (0.006) & (0.003) \\ {[0.163]} & {[0.124]}\end{array}$

Notes: The sample consists of 19,520 applications involved in the 194 lotteries with both winners and losers. The coefficients on indicators for the application being selected in a lottery at a high-achieving and at a non-highachieving school are reported. The coefficients are estimated from ordinary least squares specifications that also include the full set of individual lottery fixed effects, with the dependent variable as indicated in each row and panel. Robust standard errors that account for correlation across applications by the same student are reported in parentheses. $*=$ significance at the $10 \%$ level; ** = significance at the $5 \%$ level. 
Table 4. How much lottery-driven attrition exists and is it correlated with observable student characteristics?

\begin{tabular}{|c|c|c|c|c|c|c|}
\hline & \multicolumn{6}{|c|}{ Dependent Variables } \\
\hline & $\begin{array}{l}\text { Enrolled } \\
\text { in CPS } \\
\text { in the } 9^{\text {th }} \\
\text { grade in } \\
\text { the Fall }\end{array}$ & $\begin{array}{l}8^{\text {th }} \text { Grade } \\
\text { Reading }\end{array}$ & $\begin{array}{l}8^{\text {th }} \text { Grade } \\
\text { Math }\end{array}$ & $\begin{array}{l}\text { Free or } \\
\text { reduced } \\
\text { priced } \\
\text { lunch }\end{array}$ & $\begin{array}{l}\text { Special } \\
\text { Educ. }\end{array}$ & $\begin{array}{l}\text { Tract } \\
\text { Pov. } \\
\text { Rate }\end{array}$ \\
\hline $\begin{array}{l}\text { Win lottery to high- } \\
\text { achieving school }\end{array}$ & $\begin{array}{c}0.041 \\
(0.011) \\
{[0.890]}\end{array}$ & $\begin{array}{c}0.001 \\
(0.009) \\
{[0.537]}\end{array}$ & $\begin{array}{c}0.009 \\
(0.009) \\
{[0.580]}\end{array}$ & $\begin{array}{c}0.009 \\
(0.014) \\
{[0.799]}\end{array}$ & $\begin{array}{c}0.011 \\
(0.012) \\
{[0.093]}\end{array}$ & $\begin{array}{l}-0.003 \\
(0.005) \\
{[0.209]}\end{array}$ \\
\hline $\begin{array}{l}\text { Win lottery to other choice } \\
\text { school }\end{array}$ & $\begin{array}{c}0.011 \\
(0.009) \\
{[0.897]}\end{array}$ & $\begin{array}{l}-0.005 \\
(0.007) \\
{[0.420]}\end{array}$ & $\begin{array}{l}-0.007 \\
(0.007) \\
{[0.459]}\end{array}$ & $\begin{array}{l}-0.001 \\
(0.009) \\
{[0.904]}\end{array}$ & $\begin{array}{c}0.007 \\
(0.010) \\
{[0.132]}\end{array}$ & $\begin{array}{l}-0.001 \\
(0.004) \\
{[0.240]}\end{array}$ \\
\hline Number of observations & 19,520 & 17,024 & 17,027 & 17,470 & 17,470 & 17,457 \\
\hline $\begin{array}{l}\text { Sample limited to those } \\
\text { students enrolled in } 9^{\text {th }} \\
\text { grade in the CPS in the Fall }\end{array}$ & No & Yes & Yes & Yes & Yes & Yes \\
\hline
\end{tabular}

Notes: All regression estimates include a set of lottery fixed effects, but no other covariates. Eiker-White robust standard errors adjusted to account for the correlation of errors across applications within a single student are shown in parentheses. Control group means (i.e., the means of students who lost the lotteries) are shown in square brackets. See Tables B1 and B2 for additional evidence on selective attrition. 
Table 5. The impact of winning a lottery on the characteristics of the school attended

\begin{tabular}{|c|c|c|}
\hline \multirow{2}{*}{ Dependent Variable } & \multicolumn{2}{|c|}{ The effect of winning a lottery to ... } \\
\hline & $\begin{array}{l}\text { High-Achieving } \\
\text { School }\end{array}$ & Other Choice School \\
\hline \multicolumn{3}{|l|}{ School Type } \\
\hline \multirow[t]{3}{*}{ School for which lottery applies } & 0.363 & 0.235 \\
\hline & $(0.020)$ & $(0.013)$ \\
\hline & {$[0.082]$} & {$[0.055]$} \\
\hline \multirow[t]{3}{*}{ Any lottery school } & 0.259 & 0.186 \\
\hline & $(0.021)$ & $(0.015)$ \\
\hline & {$[0.305]$} & {$[0.286]$} \\
\hline \multirow{3}{*}{$\begin{array}{l}\text { Any school other than the student's } \\
\text { attendance area school }\end{array}$} & 0.144 & 0.099 \\
\hline & $(0.015)$ & $(0.013)$ \\
\hline & {$[0.714]$} & {$[0.669]$} \\
\hline \multirow[t]{3}{*}{ Magnet school } & 0.221 & -0.009 \\
\hline & $(0.020)$ & $(0.006)$ \\
\hline & {$[0.094]$} & {$[0.061]$} \\
\hline \multirow[t]{3}{*}{ High-achieving lottery school } & 0.338 & -0.021 \\
\hline & $(0.021)$ & $(0.008)$ \\
\hline & {$[0.120]$} & {$[0.093]$} \\
\hline \multirow[t]{3}{*}{ Any high-achieving school } & 0.276 & -0.045 \\
\hline & $(0.018)$ & $(0.012)$ \\
\hline & {$[0.432]$} & {$[0.260]$} \\
\hline \multirow[t]{3}{*}{ Other lottery school } & -0.079 & 0.207 \\
\hline & $(0.011)$ & $(0.014)$ \\
\hline & {$[0.185]$} & {$[0.193]$} \\
\hline \multirow[t]{3}{*}{ Selective admissions school } & -0.022 & -0.007 \\
\hline & $(0.013)$ & $(0.006)$ \\
\hline & {$[0.188]$} & {$[0.057]$} \\
\hline \multirow[t]{3}{*}{ Career academy } & -0.074 & -0.038 \\
\hline & $(0.012)$ & $(0.011)$ \\
\hline & {$[0.127]$} & {$[0.195]$} \\
\hline \multicolumn{3}{|l|}{ School Characteristic } \\
\hline \multirow{3}{*}{$\begin{array}{l}8^{\text {th }} \text { grade math scores of } 9^{\text {th }} \text { grader students } \\
\text { in the school (natl. percentile) }\end{array}$} & 0.042 & 0.008 \\
\hline & $(0.005)$ & $(0.003)$ \\
\hline & {$[0.510]$} & {$[0.431]$} \\
\hline \multirow{3}{*}{$\begin{array}{l}\% \text { students at or above norms on high } \\
\text { school exams (all students in the school) }\end{array}$} & 0.056 & 0.010 \\
\hline & $(0.007)$ & $(0.005)$ \\
\hline & {$[0.408]$} & {$[0.286]$} \\
\hline \multirow[t]{3}{*}{$\%$ students receiving free lunch } & -0.044 & -0.010 \\
\hline & $(0.006)$ & $(0.004)$ \\
\hline & {$[0.747]$} & {$[0.830]$} \\
\hline \multirow[t]{3}{*}{ Graduation rate } & 0.032 & 0.010 \\
\hline & $(0.004)$ & $(0.003)$ \\
\hline & {$[0.714]$} & {$[0.662]$} \\
\hline
\end{tabular}


Crime in neighborhood of the school

Ln Median HH Income in neighborhood of
the school

Distance traveled to school (in miles)
$-0.261$

(0.042)

[0.309]

0.008

(0.017)

[10.5]

0.52

(0.10)

[2.66]
$-0.159$

(0.027)

[0.184]

0.076

(0.012)

0.47

(0.07)

[2.38]

Notes: All regressions include a set of lottery fixed effects as well as student characteristics (black, white, Hispanic, male, age, $8^{\text {th }}$ grade math score, $8^{\text {th }}$ grade reading score, $7^{\text {th }}$ grade math score, $7^{\text {th }}$ grade reading score, four indicators for missing $7^{\text {th }}$ or $8^{\text {th }}$ grade achievement scores, living with biological parent in $8^{\text {th }}$ grade, attending attendance area school in $8^{\text {th }}$ grade, free lunch eligible, reduced-price lunch eligible, participating in special education program, participating in bilingual program) and neighborhood (census tract) characteristics (crime rate, poverty rate, percent Hispanic, percent black, percent high school graduates, percent home-ownership, percent not in the labor force, percent of $9^{\text {th }}-12^{\text {th }}$ graders attending private school). Eiker-White robust standard errors adjusted to account for the correlation of errors across applications within a single student are shown in parentheses. Control group means (i.e., the means of students who lost the particular lottery) are shown in square brackets. 
The effect of winning a lottery to ...

Dependent Variables

High-Achieving School Other Choice School

\begin{tabular}{|c|c|c|}
\hline \multicolumn{3}{|l|}{$9^{\text {th }}$ Grade Achievement } \\
\hline Dropped out by Spring of $9^{\text {th }}$ grade & $\begin{array}{c}-0.003 \\
(0.004) \\
{[0.012]}\end{array}$ & $\begin{array}{c}0.001 \\
(0.004) \\
{[0.022]}\end{array}$ \\
\hline Reading Score percentile & $\begin{array}{l}-0.010 \\
(0.007) \\
{[0.468]}\end{array}$ & $\begin{array}{c}-0.013 * * \\
(0.005) \\
{[0.352]}\end{array}$ \\
\hline Algebra End-of-Course Exam & $\begin{array}{l}-0.008 \\
(0.010) \\
{[0.492]}\end{array}$ & $\begin{array}{c}0.002 \\
(0.008) \\
{[0.390]}\end{array}$ \\
\hline English I End-of-Course Exam & $\begin{array}{c}0.000 \\
(0.004) \\
{[0.620]}\end{array}$ & $\begin{array}{l}-0.001 \\
(0.005) \\
{[0.567]}\end{array}$ \\
\hline Absences & $\begin{array}{l}-0.04 \\
(0.42) \\
{[7.81]}\end{array}$ & $\begin{array}{c}0.40 \\
(0.41) \\
{[10.43]}\end{array}$ \\
\hline Total Course Credits & $\begin{array}{c}0.03 \\
(0.16) \\
{[27.8]} \\
\end{array}$ & $\begin{array}{l}-0.05 \\
(0.11) \\
{[27.5]}\end{array}$ \\
\hline \multicolumn{3}{|l|}{$10^{\text {th }}$ Grade Achievement $^{\text {a }}$} \\
\hline Dropped out by Spring of $10^{\text {th }}$ Grade & $\begin{array}{l}-0.003 \\
(0.007) \\
{[0.044]}\end{array}$ & $\begin{array}{l}-0.007 \\
(0.008) \\
{[0.082]}\end{array}$ \\
\hline Reading Score & $\begin{array}{c}-0.020 * * \\
(0.009) \\
{[0.523]}\end{array}$ & $\begin{array}{c}0.000 \\
(0.009) \\
{[0.399]}\end{array}$ \\
\hline Geometry End-of-Course Exam & $\begin{array}{c}0.014 \\
(0.017) \\
{[0.621]}\end{array}$ & $\begin{array}{c}0.012 \\
(0.007) \\
{[0.508]}\end{array}$ \\
\hline English II End-of-Course Exam & $\begin{array}{l}-0.012 \\
(0.011) \\
{[0.548]}\end{array}$ & $\begin{array}{c}0.011 \\
(0.007) \\
{[0.481]}\end{array}$ \\
\hline Absences & $\begin{array}{l}-0.13 \\
(0.53) \\
{[9.19]}\end{array}$ & $\begin{array}{c}0.89 \\
(0.68) \\
{[11.69]}\end{array}$ \\
\hline Total Course Credits & $\begin{array}{c}0.01 \\
(0.15) \\
{[27.9]} \\
\end{array}$ & $\begin{array}{c}-0.43 \\
(0.33) \\
{[27.8]}\end{array}$ \\
\hline
\end{tabular}

Notes: All regressions include a set of lottery fixed effects as well as student characteristics (black, white, Hispanic, male, age, $8^{\text {th }}$ grade math score, $8^{\text {th }}$ grade reading score, $7^{\text {th }}$ grade math score, $7^{\text {th }}$ grade reading score, four indicators for missing $7^{\text {th }}$ or $8^{\text {th }}$ grade achievement scores, living with biological parent in $8^{\text {th }}$ grade, attending attendance area 
school in $8^{\text {th }}$ grade, free lunch eligible, reduced-price lunch eligible, participating in special education program, participating in bilingual program) and neighborhood (census tract) characteristics (crime rate, poverty rate, percent Hispanic, percent black, percent high school graduates, percent home-ownership, percent not in the labor force, percent of $9^{\text {th }}-12^{\text {th }}$ graders attending private school). Eiker-White robust standard errors adjusted to account for the correlation of errors within high school are shown in parentheses. Control group means (i.e., the means of students who lost the particular lottery) are shown in square brackets. ${ }^{\mathrm{a}}$ The following outcomes are limited to the 2000 cohort: reading score, geometry score, English 2 score. 
Table 7. Sensitivity to alternative specifications and classifications of schools

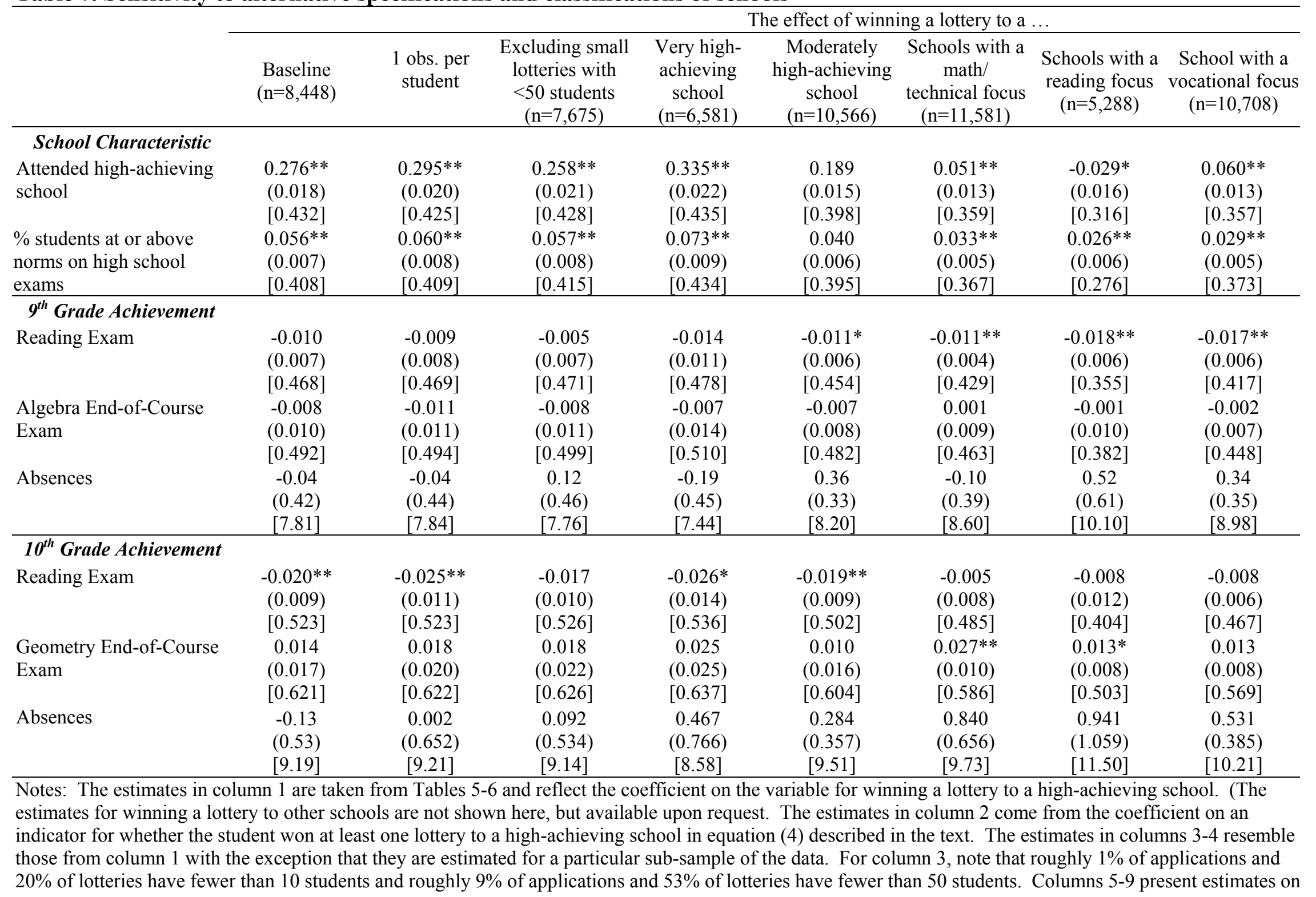


the effect of winning a lottery to various school and program types. Very high-achieving schools are defined as those in the three highest-achieving schools in our analysis sample (see Table 1). They are roughly in the top $20 \%$ of schools in the CPS and they are also the set of magnet high schools. Moderately highachieving schools are defined as those in the top 30\% of schools in the CPS, which includes the eight highest-achieving schools from our analysis sample from Table 1. The effect of winning a lottery to other choice schools are not shown here, although the overall pattern of results does not differ considerably from the main effects shown on Tables 5-6. 


\section{Table 8. Reduced form estimates by student characteristic}

The effect of winning a lottery to a high-achieving school for the following subgroups of students...

\begin{tabular}{|c|c|c|c|c|c|c|c|}
\hline & $\begin{array}{l}\text { All students } \\
\text { (i.e., those } \\
\text { applying to } \\
\text { high-achieving } \\
\text { school) } \\
(n=8,448)\end{array}$ & $\begin{array}{c}\text { Black } \\
(n=3,568)\end{array}$ & $\begin{array}{l}\text { Hispanic } \\
(\mathrm{n}=3,146)\end{array}$ & $\begin{array}{c}\text { Male } \\
(\mathrm{n}=3,512)\end{array}$ & $\begin{array}{l}\text { Below average } \\
8^{\text {th }} \text { grade test } \\
\text { scores } \\
(n=3,284)\end{array}$ & $\begin{array}{l}\text { Home-School } \\
\text { Distance } \\
>2 \text { miles } \\
(\mathrm{n}=4,143)\end{array}$ & $\begin{array}{c}\text { Alternative } \\
\text { school has scores } \\
\text { below national } \\
\text { norms } \\
(\mathrm{n}=4,735)\end{array}$ \\
\hline \multicolumn{8}{|l|}{ School Characteristic } \\
\hline Attended high-achieving school & $\begin{array}{c}0.276 * * \\
(0.018) \\
{[0.432]}\end{array}$ & $\begin{array}{c}0.276 * * \\
(0.030) \\
{[0.394]}\end{array}$ & $\begin{array}{c}0.255 * * \\
(0.030) \\
{[0.402]}\end{array}$ & $\begin{array}{c}0.267 * * \\
(0.028) \\
{[0.431]}\end{array}$ & $\begin{array}{c}0.425 * * \\
(0.034) \\
{[0.173]}\end{array}$ & $\begin{array}{c}0.239 * * \\
(0.020) \\
{[0.603]}\end{array}$ & $\begin{array}{c}0.366 * * \\
(0.026) \\
{[0.239]}\end{array}$ \\
\hline $\begin{array}{l}\% \text { students at or above norms on high } \\
\text { school exams }\end{array}$ & $\begin{array}{c}0.056 * * \\
(0.007) \\
{[0.408]} \\
\end{array}$ & $\begin{array}{c}0.053 * * \\
(0.010) \\
{[0.345]}\end{array}$ & $\begin{array}{c}0.050 * * \\
(0.012) \\
{[0.404]}\end{array}$ & $\begin{array}{c}0.055 * * \\
(0.010) \\
{[0.416]}\end{array}$ & $\begin{array}{c}0.090 * * \\
(0.011) \\
{[0.267]}\end{array}$ & $\begin{array}{c}0.032 * * \\
(0.009) \\
{[0.486]}\end{array}$ & $\begin{array}{c}0.079 * * \\
(0.008) \\
{[0.289]}\end{array}$ \\
\hline \multicolumn{8}{|l|}{$9^{\text {th }}$ Grade Achievement } \\
\hline Reading Exam & $\begin{array}{l}-0.010 \\
(0.007) \\
{[0.468]}\end{array}$ & $\begin{array}{l}-0.013 \\
(0.013) \\
{[0.410]}\end{array}$ & $\begin{array}{c}-0.018 * * \\
(0.009) \\
{[0.473]}\end{array}$ & $\begin{array}{c}0.000 \\
(0.009) \\
{[0.473]}\end{array}$ & $\begin{array}{l}-0.008 \\
(0.009) \\
{[0.279]}\end{array}$ & $\begin{array}{c}0.002 \\
(0.009) \\
{[0.514]}\end{array}$ & $\begin{array}{l}-0.008 \\
(0.008) \\
{[0.335]}\end{array}$ \\
\hline Algebra End-of-Course Exam & $\begin{array}{l}-0.008 \\
(0.010) \\
{[0.492]}\end{array}$ & $\begin{array}{l}-0.006 \\
(0.012) \\
{[0.430]}\end{array}$ & $\begin{array}{l}-0.009 \\
(0.018) \\
{[0.494]}\end{array}$ & $\begin{array}{l}-0.017 \\
(0.013) \\
{[0.506]}\end{array}$ & $\begin{array}{l}-0.013 \\
(0.015) \\
{[0.371]}\end{array}$ & $\begin{array}{l}-0.010 \\
(0.010) \\
{[0.527]}\end{array}$ & $\begin{array}{l}-0.005 \\
(0.013) \\
{[0.400]}\end{array}$ \\
\hline Absences & $\begin{array}{l}-0.04 \\
(0.42) \\
{[7.81]}\end{array}$ & $\begin{array}{l}1.35 * \\
(0.72) \\
{[9.15]}\end{array}$ & $\begin{array}{c}-1.53 * * \\
(0.44) \\
{[7.12]}\end{array}$ & $\begin{array}{l}-0.25 \\
(0.64) \\
{[7.66]}\end{array}$ & $\begin{array}{c}1.39 * \\
(0.76) \\
{[10.17]}\end{array}$ & $\begin{array}{c}0.15 \\
(0.42) \\
{[6.94]}\end{array}$ & $\begin{array}{c}0.88 \\
(0.68) \\
{[9.39]}\end{array}$ \\
\hline \multicolumn{8}{|l|}{$10^{\text {th }}$ Grade Achievement } \\
\hline Reading Exam & $\begin{array}{c}-0.020 * * \\
(0.009) \\
{[0.523]}\end{array}$ & $\begin{array}{c}-0.053 * * \\
(0.018) \\
{[0.464]}\end{array}$ & $\begin{array}{l}-0.001 \\
(0.012) \\
{[0.522]}\end{array}$ & $\begin{array}{l}-0.008 \\
(0.011) \\
{[0.516]}\end{array}$ & $\begin{array}{c}-0.021 \\
(0.017) \\
{[0.329]}\end{array}$ & $\begin{array}{c}-0.011 \\
(0.012) \\
{[0.567]}\end{array}$ & $\begin{array}{c}-0.006 \\
(0.016) \\
{[0.372]}\end{array}$ \\
\hline Geometry End-of-Course Exam & $\begin{array}{c}0.014 \\
(0.017) \\
{[0.621]}\end{array}$ & $\begin{array}{l}-0.023 \\
(0.031) \\
{[0.554]}\end{array}$ & $\begin{array}{c}0.036 * * \\
(0.017) \\
{[0.616]}\end{array}$ & $\begin{array}{c}0.038 * * \\
(0.016) \\
{[0.638]}\end{array}$ & $\begin{array}{c}0.056 \\
(0.040) \\
{[0.473]}\end{array}$ & $\begin{array}{c}0.008 \\
(0.018) \\
{[0.662]}\end{array}$ & $\begin{array}{c}0.021 \\
(0.022) \\
{[0.508]}\end{array}$ \\
\hline Absences & $\begin{array}{l}-0.13 \\
(0.53) \\
{[9.19]}\end{array}$ & $\begin{array}{c}0.527 \\
(0.945) \\
{[11.45]}\end{array}$ & $\begin{array}{c}-1.175^{* *} \\
(0.338) \\
{[8.05]}\end{array}$ & $\begin{array}{c}-0.262 \\
(0.835) \\
{[8.91]}\end{array}$ & $\begin{array}{c}1.286 \\
(1.060) \\
{[11.98]}\end{array}$ & $\begin{array}{c}-0.197 \\
(0.652) \\
{[8.57]}\end{array}$ & $\begin{array}{c}0.033 \\
(0.574) \\
{[11.15]}\end{array}$ \\
\hline
\end{tabular}

Note: The estimates shown above come from specifications identical to those which produced the main effects in Tables 5-6 with the only difference being that they are estimated on specific sub-samples of students. Robust standard errors that account for correlation in errors discussed in previous tables are shown in parentheses. Control group means are shown in square brackets. The home-school distance refers to the distance between the student's $9^{\text {th }}$ grade residence and 
$9^{\text {th }}$ grade school. The sample median is 2 miles. The measure of $8^{\text {th }}$ grade test scores is a composite of reading and math, and represents students below the $50^{\text {th }}$ percentile on the national achievement distribution. Since we cannot determine definitively which school was the next best alternative for any given student, we use a probabilistic approach to determine the likely achievement level at the school a student would have attended had the student not won the lottery. We

calculate the expected peer quality at alternatives to the application school as the average achievement of $9^{\text {th }}$ grade entrants at Fall schools for students of similar ability (in the same quintile according to $8^{\text {th }}$ grade math and reading composite scores) and assigned to the same attendance area high school. The effect of

winning a lottery to other choice schools are not shown here, although the overall pattern of results does not differ considerably from the main effects shown on Tables 5-6. 
The effect of winning a lottery to ...

\begin{tabular}{|c|c|c|}
\hline Dependent Variables & $\begin{array}{l}\text { High-Achieving } \\
\text { School }\end{array}$ & $\begin{array}{c}\text { Other } \\
\text { Choice School }\end{array}$ \\
\hline $\begin{array}{c}\text { Parental Support and Supervision } \\
\text { Parents help with homework most or all of the time }\end{array}$ & $\begin{array}{c}-0.053 * \\
(0.031) \\
{[0.204]}\end{array}$ & $\begin{array}{c}0.025 \\
(0.025) \\
{[0.248]}\end{array}$ \\
\hline $\begin{array}{l}\text { Parents check if homework is done most or all of the } \\
\text { time }\end{array}$ & $\begin{array}{c}-0.075 * * \\
(0.039) \\
{[0.385]}\end{array}$ & $\begin{array}{c}0.025 \\
(0.025) \\
{[0.392]}\end{array}$ \\
\hline Parents regularly discuss courses with student & $\begin{array}{c}0.113 * * \\
(0.037) \\
{[0.429]}\end{array}$ & $\begin{array}{c}0.012 \\
(0.030) \\
{[0.403]}\end{array}$ \\
\hline $\begin{array}{l}\text { Parents regularly discuss school activities with } \\
\text { student }\end{array}$ & $\begin{array}{c}0.074 * \\
(0.043) \\
{[0.518]}\end{array}$ & $\begin{array}{c}-0.067 * * \\
(0.028) \\
{[0.475]}\end{array}$ \\
\hline $\begin{array}{l}\text { Parents regularly discuss things child studied in } \\
\text { school with student }\end{array}$ & $\begin{array}{c}0.047 \\
(0.038) \\
{[0.521]}\end{array}$ & $\begin{array}{c}0.007 \\
(0.029) \\
{[0.472]}\end{array}$ \\
\hline Parents regularly discuss homework with student & $\begin{array}{c}0.082 * * \\
(0.040) \\
{[0.525]}\end{array}$ & $\begin{array}{c}0.032 \\
(0.029) \\
{[0.504]}\end{array}$ \\
\hline Parents closely supervise the student & $\begin{array}{c}0.094 \\
(0.200) \\
{[6.51]}\end{array}$ & $\begin{array}{c}-0.005 \\
(0.129) \\
{[6.50]}\end{array}$ \\
\hline $\begin{array}{l}\text { Other Outcome Measures } \\
\text { Incidence of disciplinary action vs. student at school }\end{array}$ & $\begin{array}{c}-0.297 * * \\
(0.146) \\
{[1.90]}\end{array}$ & $\begin{array}{c}0.058 \\
(0.152) \\
{[2.20]}\end{array}$ \\
\hline Arrested by police in past year & $\begin{array}{c}-0.050 * * \\
(0.024) \\
{[0.089]}\end{array}$ & $\begin{array}{l}-0.012 \\
(0.019) \\
{[0.127]}\end{array}$ \\
\hline Likes school & $\begin{array}{c}0.148 \\
(0.125) \\
{[4.14]}\end{array}$ & $\begin{array}{c}-0.063 \\
(0.111) \\
{[4.23]}\end{array}$ \\
\hline Expects to graduate college & $\begin{array}{c}0.011 \\
(0.027) \\
{[0.865]}\end{array}$ & $\begin{array}{c}0.015 \\
(0.026) \\
{[0.805]}\end{array}$ \\
\hline School safety & $\begin{array}{c}0.111 \\
(0.196) \\
{[5.30]}\end{array}$ & $\begin{array}{c}0.115 \\
(0.104) \\
{[5.15]}\end{array}$ \\
\hline
\end{tabular}


Notes: The sample is limited to students in the 2000 cohort and excludes students who applied to three schools (Von Steueben, Roosevelt and Lake View) that did not administer the survey. All regressions include a set of lottery fixed effects as well as student characteristics (black, white, Hispanic, male, age, $8^{\text {th }}$ grade math score, $8^{\text {th }}$ grade reading score, $7^{\text {th }}$ grade math score, $7^{\text {th }}$ grade reading score, four indicators for missing $7^{\text {th }}$ or $8^{\text {th }}$ grade achievement scores, living with biological parent in $8^{\text {th }}$ grade, attending attendance area school in $8^{\text {th }}$ grade, free lunch eligible, reducedprice lunch eligible, participating in special education program, participating in bilingual program) and neighborhood (census tract) characteristics (crime rate, poverty rate, percent Hispanic, percent black, percent high school graduates, percent home-ownership, percent not in the labor force, percent of $9^{\text {th }}-12^{\text {th }}$ graders attending private school). Eiker-White robust standard errors adjusted to account for the correlation of errors within high school are shown in parentheses. Control group means (i.e., the means of students who lost the particular lottery) are shown in square brackets. The composite survey measures are all continuous variables with the following standard deviations: 2.25 for parent supervision; 1.87 for likes school, 1.98 for school safety, 1.47 for studentteacher trust, 1.10 for peer behavior and 2.02 for disciplinary action. 